\title{
Geochemistry of a Late Quaternary loess-paleosol sequence in central Argentina: Implications for weathering, sedimentary recycling and provenance
}

\author{
Verena A. Campodonico ${ }^{\mathrm{a}, *}$, Sabrina Rouzaut ${ }^{\mathrm{b}}$, Andrea I. Pasquini ${ }^{\mathrm{a}, \mathrm{b}}$ \\ ${ }^{a}$ Centro de Investigaciones en Ciencias de la Tierra (CICTERRA), Consejo Nacional de Investigaciones Científicas y Técnicas (CONICET) y Universidad Nacional de \\ Córdoba, Av. Vélez Sarsfield 1611, X5016CGA Córdoba, Argentina \\ ${ }^{\mathrm{b}}$ Facultad de Ciencias Exactas, Físicas y Naturales, Universidad Nacional de Córdoba, Av. Vélez Sarsfield 1611, X5016CGA Córdoba, Argentina
}

\section{A R T I C L E I N F O}

Handling Editor: David Laird

Keywords:

Weathering indices

Mass balance

Loess source

Corralito I loess-paleosol sequence

\begin{abstract}
A B S T R A C T
A loess-paleosol sequence in the Pampean Plain, central Argentina was analyzed geochemically, in order to evaluate the weathering signature and sedimentary recycling as well as to analyze the origin of these loessic sediments. Corralito I sequence is composed of three paleosols and a buried soil separated by loess layers. The loess-paleosol sequence shows a similar geochemical composition throughout, suggesting that pedogenesis has not been intense enough to mask the chemical signature of the parent material. Weathering indices (CIA, CIW, PIA and LWI), elemental ratios $\left(\mathrm{Rb} / \mathrm{Sr}, \mathrm{CaO} / \mathrm{TiO}_{2}\right.$ and $\left.\mathrm{Na}_{2} \mathrm{O} / \mathrm{TiO}_{2}\right)$, and the $\mathrm{A}-\mathrm{CN}-\mathrm{K}$ ternary diagram indicate incipient chemical alteration for this sequence, compatible with a weathering-limited regime. As expected, paleosols (CIAs $\sim 60$ ) exhibit a slightly higher chemical alteration than loess layers (CIAs 58). Mass balance calculations reveal the losses of some major oxides (i.e., $\mathrm{CaO}, \mathrm{Na}_{2} \mathrm{O}$ ) and $\mathrm{Sr}$ in the buried soil and paleosols compared to its loess mantles, reflecting the weathering of plagioclase. Besides, the losses of $\mathrm{K}_{2} \mathrm{O}$ and $\mathrm{Ba}$ in the buried soil and paleosols I and II, when compared to its loess layers, suggest the chemical alteration of Kfeldspar. The chemical alteration of volcanic glass is evidenced by the relative losses of As in almost all levels. Conversely, the relative gains of $\mathrm{Fe}_{2} \mathrm{O}_{3}$ and $\mathrm{MgO}$ reveal that pyroxenes and amphiboles or Fe oxy-hydroxides are concentrated in paleosols and the buried soil compared to its loess mantles. The geochemical approach used to constrain the origin of these Pampean Plain loessic sediments indicates they derive mainly from the Andean region. Conversely, the Pampean ranges, the Paraná River basin and Uruguayan Precambrian outcrops, which were pointed out as minor local sources, do not contribute significantly to the loess deposits. This work also shows that Corralito I loess-paleosol sequence and other loess samples from Argentina do not evidence sedimentary recycling, suggesting that these Pampean Plain loess deposits are mainly composed by young materials derived from undifferentiated volcanic rocks.
\end{abstract}

\section{Introduction}

The largest loess deposits in South America blanket the southern plains of the continent between $23^{\circ}$ and $38^{\circ} \mathrm{S}$ (Zárate, 2003; Fig. 1). During the past 35 years, several works dealing with its distribution, composition, magnetostratigraphy, age, fossil contents, source areas and palaeoenvironmental implications have been conducted. Loesspaleosol sequences constitute important archives of continental climate change during the Quaternary (e.g., Kemp, 2001; Frechen et al., 2003; Muhs et al., 2003; Porter, 2007; Kühn et al., 2013). Besides, the distribution and origin of loess can give important information about past atmospheric circulation (e.g., Pye, 1995; Muhs and Budahn, 2006).
The chemical composition of loessic sediments reveals the composition of the dust sources and reflects the modifications induced during transport and post-depositional weathering (e.g., Ahmad and Chandra, 2013). Different geochemical approaches have been used to analyze chemical weathering and provenance in loess-paleosol sequences in various regions of the world (e.g., Muhs et al., 2001; Muhs and Budahn, 2006; Újvári et al., 2008; Ahmad and Chandra, 2013; Újvári et al., 2014; Li et al., 2016; Babeesh et al., 2017; Sun et al., 2018).

Classic approaches for weathering analysis include the use of alteration indices based on the ratio between mobile elements and one immobile component, such as the Chemical Index of Alteration (CIA; Nesbitt and Young, 1982), the Chemical Index of Weathering (CIW;

\footnotetext{
* Corresponding author.

E-mail address: vcampodonico@unc.edu.ar (V.A. Campodonico).
} 


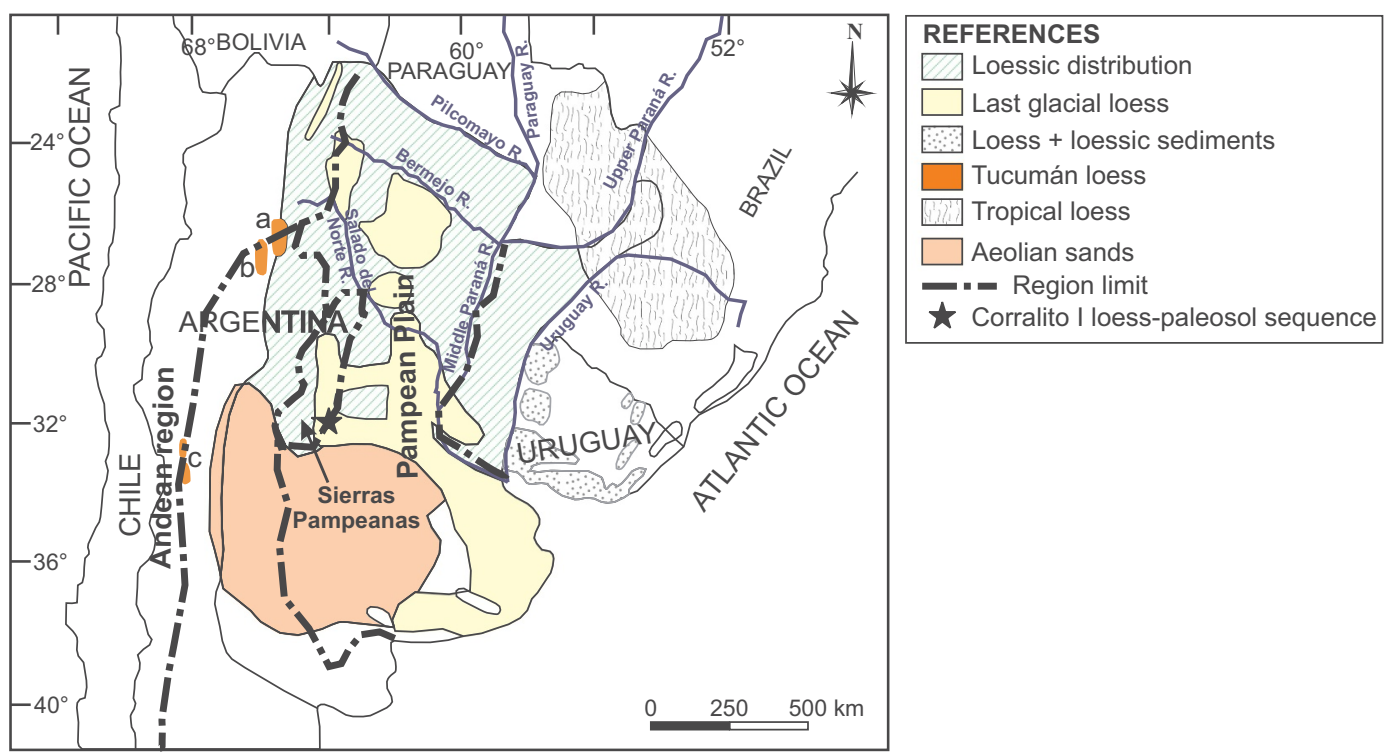

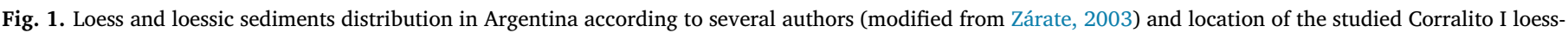

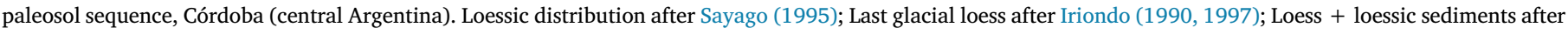

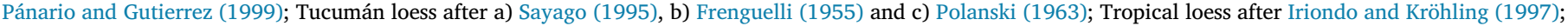
Aeolian sands after Zárate (2003).

Harnois, 1988), and the Plagioclase Index of Alteration (PIA; Fedo et al., 1995), among others. Likewise, mass balance estimations and trace elements ratios have also been used as proxies of paleo-weathering conditions (e.g., Yang et al., 2006; Tugulan et al., 2016; Sun et al., 2018). It is well known that weathering intensity is related to several factors such as climate, relief, biota, time, and the bedrock characteristics. Among them, climate results substantial since it determines water availability, ambient temperature, and then, chemical reaction kinetics (e.g., Depetris et al., 2014). Other authors such as Potter et al. (2005) clearly recognized the relationship between rainfall and temperature, weathering products and soil development.

On the other hand, the knowledge of loess sources is crucial for the understanding of paleowind directions and climate change in a particular region (Pye, 1995). In this sense, geochemistry constitutes a reliable tool for identifying the contribution of different dust sources.

The sediments that cover the Pampean Plain in Argentina were originally defined as "loess" by Heusser and Claraz (1866). Several works devoted to this loess deposits have been carried out from the early twentieth century (e.g., Döering, 1907; Frenguelli, 1918), and subsequently (Teruggi, 1957; Iriondo, 1990, 1997; Iriondo and Kröhling, 1995). Zárate (2003) presented a summary of the distribution of loess sediments in Southern South America. Although, the origin of such deposits remains controversial, many investigators agree that the source area is dominantly volcaniclastic and is located in the Andean region from where the material was transported by the westerly winds (e.g., Teruggi, 1957; Iriondo, 1997; Morrás, 1999; Smith et al., 2003; Zárate, 2003; Gili et al., 2017). Morrás (1999) pointed out that loess also includes minor amounts of particles from other local sources such as the Pampean ranges, and the Paraná River basin. The Sierras Pampeanas provided particles of metamorphic and igneous rocks (Cantú and Degiovanni, 1984; Cantú, 1992; Kröhling, 1999). Besides, Uruguayan Precambrian outcrops were also suggested as minor local sources of Pampean loess (Zárate et al., 2002). Argüello et al. (2012) defined this material as reworked loess in the sense of Pye and Sherwin (1999), i.e., loess that has been locally transported and redeposited by colluvial or fluvial processes, but retains most of the characteristics of wind-blown deposits. Most of the studies mentioned above are focused on the origin and distribution of such deposits. However, references regarding the geochemistry of loess deposits in the Argentina's Pampean region are scarce (e.g., Gallet et al., 1998; Smedley et al., 2002;
Nicolli et al., 2010; Pasquini et al., 2017).

In the present study, a loess-paleosol sequence located in central Argentina (Córdoba province) was examined. This sequence, named Corralito I ( $32^{\circ} 00^{\prime \prime} 7^{\prime \prime} \mathrm{S}, 64^{\circ} 11^{\prime} 08^{\prime \prime} \mathrm{W}, 469 \mathrm{~m}$ a.s.l.; Fig. 1), was previously described, sampled and morphologically analyzed (Argüello et al., 2012; Rouzaut et al., 2012a, 2013, 2015; Rouzaut and Orgeira, 2017). Frechen et al. (2009) established, by means of luminescence methods, a Late Pleistocene - Holocene age for this loess-paleosol sequence. The magnetic properties of Corralito I sequence were also examined in detail (Rouzaut et al., 2012a, 2015). The aims of this study are: 1) to characterize the geochemical composition of the loess-paleosol sequence; 2) to analyze the weathering signature and establish relative gains and losses of major and trace elements; 3) to constrain the provenance of loessic sediments; and 4) to detect geochemical evidences of sedimentary recycling.

\section{Corralito I loess-paleosol sequence}

Loess and loessic sediments distribution in Argentina according to several authors is shown in Fig. 1. Sayago (1995) proposed a subdivision into Neotropical and Pampean loess considering the general geographical distribution of loess in areas with different climatic conditions. According to this classification, the Neotropical loess (including primary and reworked loess) extends from $20^{\circ}$ to $30^{\circ} \mathrm{S}$ along the present-day subtropical area of the Chaco Plain as well as the pre-Andean mountains and intermountain valleys to the west, whereas the Pampean loess covers the temperate region south of $30^{\circ} \mathrm{S}$ (Sayago, 1995). The loess-paleosol sequence Corralito I is located in Córdoba Province, central Argentina in the Pampean Plain region (Fig. 1). It is situated on the geomorphological sub-region known as Plataforma Basculada Ondulada (Undulated Tilted Platform; Gorgas et al., 2006), later defined as Fluvio-Aeolian Central Plain by Carignano et al. (2014). The landscape is made up of long and rounded hills, with slopes ranging between 1 and $3 \%$ and heights of $\sim 10 \mathrm{~m}$. They are usually affected by rill erosion, both rectilinear and meandering, and in some cases gullies are also developed.

Corralito I sequence is exposed in a gully, which was formed by extreme rainfall during the hydrological year 1978/1979 (Argüello et al., 2006), and it was previously described by Rouzaut et al. (2012a, 2015) and Rouzaut and Orgeira (2017). This gully exposure is about 

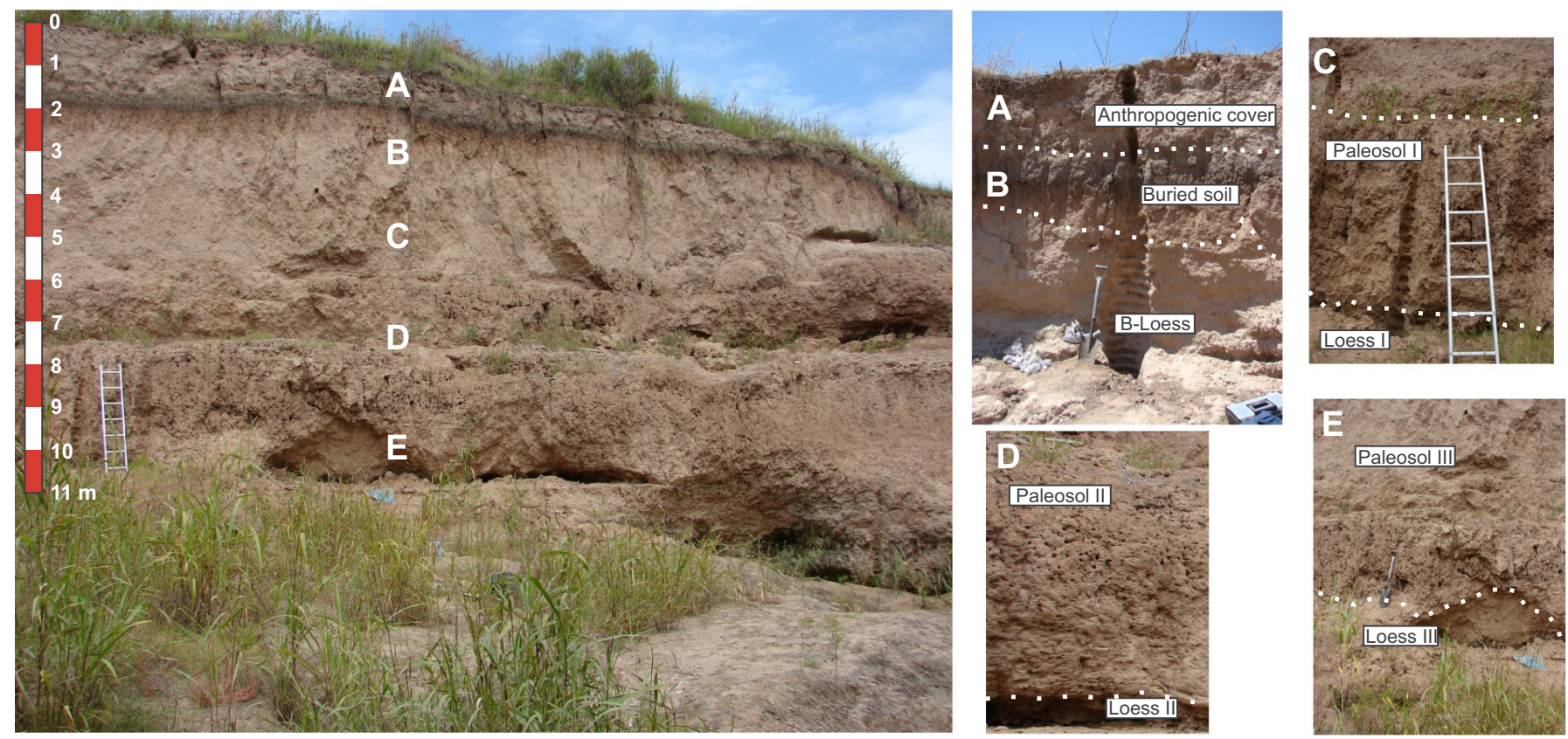

Fig. 2. Field photograph of Corralito I loess-paleosol sequence with close views of each paleosol-loess sequence.

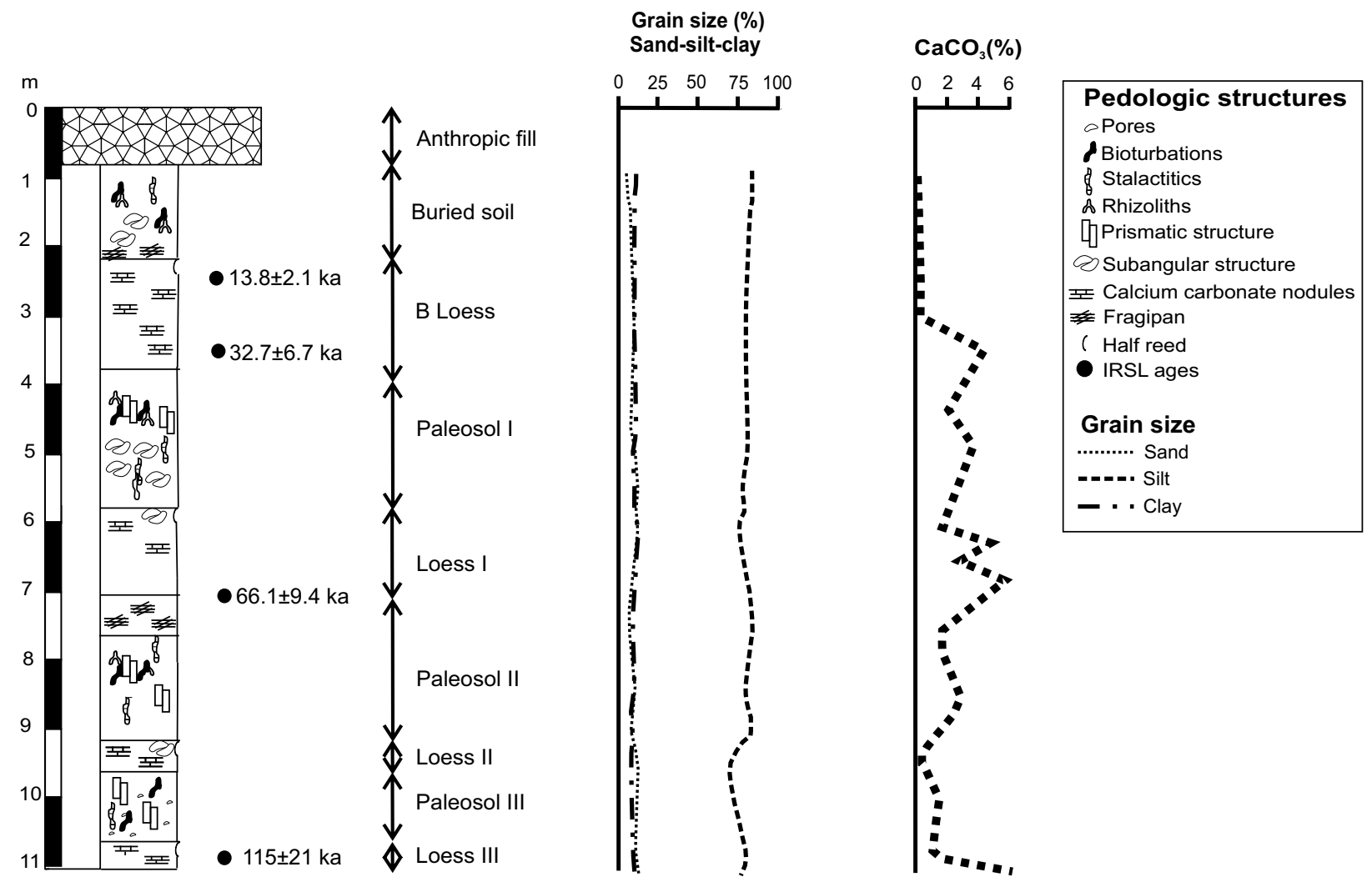

Fig. 3. Stratigraphic column of Corralito I loess-paleosol sequence with grain-size distribution and calcium carbonate content (modified from Rouzaut and Orgeira, 2017). IRSL ages after Frechen et al. (2009).

$11 \mathrm{~m}$ thick and includes a sequence of three paleosols (identified as paleosol III, paleosol II, and paleosol I, from oldest to youngest) and a buried soil (paleopedological nomenclature after Reuter, 2000), intercalated with loess mantles (loess III, loess II, loess I, and B loess, from oldest to youngest) (Figs. 2 and 3). The buried soil is covered by layered sediments of about $1 \mathrm{~m}$ thick. Frechen et al. (2009) pointed out that this landfill originated from rapid transport of very dry sediment aggregates during or shortly after torrential rainfall. Human refuse was recognized between 0.40 and $0.60 \mathrm{~m}$ below the surface, and constitutes a time marker for these sediments, indicating that they are younger than 30 years. Although this anthropogenic landfill at the top of Corralito I sequence covers most of the gully at the sampling site, it was not considered in the analysis because it is not relevant to the present study; instead, the cultivated neosol was analyzed. This landfill does not have 
Table 1

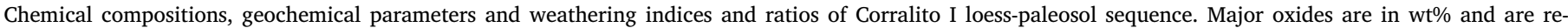
calculated to $100 \%$ free of volatile. Trace and rare earth elements are in ppm.

\begin{tabular}{|c|c|c|c|c|c|c|c|c|c|c|c|c|c|c|}
\hline & \multirow[t]{2}{*}{ Detection limit } & \multicolumn{3}{|c|}{ Neosol-Corralito Series } & \multirow{2}{*}{$\begin{array}{l}\text { Buried soil } \\
\text { CORI BS }\end{array}$} & \multicolumn{3}{|l|}{$\begin{array}{l}\text { B- } \\
\text { Loess }\end{array}$} & \multirow{2}{*}{$\begin{array}{l}\text { Loess I } \\
\text { CORI } \\
\text { PI } \\
\text { Loess I }\end{array}$} & \multicolumn{2}{|l|}{ Paleosol II } & \multirow{2}{*}{$\begin{array}{l}\text { Loess II } \\
\text { CORI } \\
\text { PII } \\
\text { Loess II }\end{array}$} & \multirow[t]{2}{*}{ Paleosol III } & \multirow{2}{*}{$\begin{array}{l}\text { Loess III } \\
\text { CORI PII } \\
\text { Loess III }\end{array}$} \\
\hline & & Ap & $\mathrm{Bw}$ & $\mathrm{Ck}$ & & $\begin{array}{l}\text { COR I } \\
\text { B- } \\
\text { Loess }\end{array}$ & CORI PI-1 & CORI PI-2 & & CORI PII-1 & CORI PII-2 & & & \\
\hline $\mathrm{SiO}_{2}$ & 0.01 & 68.15 & 68.34 & 66.96 & 64.60 & 66.63 & 65.41 & 66.56 & 67.05 & 66.16 & 68.05 & 69.26 & 67.51 & 67.06 \\
\hline $\mathrm{Al}_{2} \mathrm{O}_{3}$ & 0.01 & 16.48 & 16.34 & 17.25 & 19.17 & 17.27 & 17.15 & 16.61 & 16.37 & 16.83 & 16.50 & 15.83 & 16.92 & 16.49 \\
\hline $\mathrm{Fe}_{2} \mathrm{O}_{3(\mathrm{~T})}$ & 0.01 & 5.47 & 5.95 & 6.03 & 6.87 & 5.67 & 5.86 & 5.71 & 5.07 & 5.87 & 4.84 & 4.34 & 5.49 & 5.53 \\
\hline $\mathrm{MnO}$ & 0.001 & 0.08 & 0.10 & 0.10 & 0.09 & 0.09 & 0.10 & 0.10 & 0.08 & 0.08 & 0.07 & 0.08 & 0.08 & 0.09 \\
\hline $\mathrm{MgO}$ & 0.01 & 1.49 & 1.56 & 1.75 & 1.77 & 1.71 & 1.99 & 1.81 & 1.64 & 1.95 & 1.41 & 1.21 & 1.72 & 1.79 \\
\hline $\mathrm{CaO}$ & 0.01 & 2.15 & 1.89 & 1.89 & 1.61 & 2.18 & 2.46 & 2.28 & 2.67 & 2.37 & 1.97 & 2.01 & 1.71 & 2.46 \\
\hline $\mathrm{Na}_{2} \mathrm{O}$ & 0.01 & 2.44 & 2.12 & 2.12 & 1.94 & 2.53 & 2.65 & 2.56 & 2.98 & 2.33 & 2.70 & 2.99 & 2.31 & 2.49 \\
\hline $\mathrm{K}_{2} \mathrm{O}$ & 0.01 & 2.75 & 2.70 & 2.88 & 2.88 & 2.89 & 3.31 & 3.32 & 3.18 & 3.36 & 3.56 & 3.49 & 3.35 & 3.09 \\
\hline $\mathrm{TiO}_{2}$ & 0.001 & 0.81 & 0.81 & 0.82 & 0.88 & 0.83 & 0.82 & 0.78 & 0.71 & 0.77 & 0.71 & 0.67 & 0.75 & 0.78 \\
\hline $\mathrm{P}_{2} \mathrm{O}_{5}$ & 0.01 & 0.18 & 0.19 & 0.20 & 0.19 & 0.20 & 0.26 & 0.28 & 0.24 & 0.26 & 0.19 & 0.13 & 0.16 & 0.22 \\
\hline $\mathrm{Sc}$ & 1 & 12 & 14 & 15 & 16 & 13 & 14 & 14 & 12 & 13 & 11 & 10 & 13 & 13 \\
\hline V & 5 & 85 & 86 & 91 & 88 & 91 & 105 & 98 & 89 & 93 & 76 & 67 & 84 & 90 \\
\hline $\mathrm{Ba}$ & 3 & 541 & 520 & 560 & 518 & 576 & 552 & 561 & 579 & 524 & 619 & 624 & 598 & 551 \\
\hline $\mathrm{Sr}$ & 2 & 284 & 238 & 253 & 234 & 301 & 319 & 294 & 326 & 269 & 265 & 285 & 260 & 289 \\
\hline As & 5 & 6 & 6 & $<5.0$ & 7 & 9 & 11 & 12 & 10 & 11 & 10 & 10 & 9 & 9 \\
\hline $\mathrm{Y}$ & 2 & 26 & 28 & 28 & 28 & 26 & 26 & 25 & 25 & 25 & 26 & 26 & 26 & 24 \\
\hline $\mathrm{Zr}$ & 4 & 192 & 197 & 180 & 199 & 212 & 199 & 198 & 204 & 181 & 208 & 235 & 203 & 214 \\
\hline $\mathrm{Cr}$ & 20 & 50 & 50 & 50 & 50 & 50 & 50 & 50 & 40 & 50 & 40 & 40 & 50 & 50 \\
\hline Co & 1 & 10 & 12 & 12 & 13 & 11 & 12 & 11 & 10 & 10 & 8 & 7 & 10 & 11 \\
\hline $\mathrm{Ni}$ & 20 & 20 & 30 & 30 & 30 & 30 & 20 & 20 & 20 & 20 & $<20$ & $<20$ & 20 & 30 \\
\hline $\mathrm{Zn}$ & 30 & 80 & 90 & 90 & 100 & 80 & 90 & 90 & 80 & 90 & 80 & 70 & 80 & 90 \\
\hline $\mathrm{Rb}$ & 2 & 101 & 112 & 112 & 125 & 107 & 107 & 114 & 105 & 117 & 128 & 120 & 124 & 108 \\
\hline Cs & 0.5 & 7.0 & 8.1 & 8.3 & 9.9 & 7.6 & 7.8 & 8.1 & 6.7 & 8.5 & 8.2 & 7.1 & 8.1 & 7.4 \\
\hline $\mathrm{Hf}$ & 0.2 & 4.3 & 4.8 & 4.3 & 4.9 & 5.2 & 4.6 & 4.6 & 4.8 & 4.6 & 4.7 & 5.4 & 5.0 & 4.9 \\
\hline Ta & 0.1 & 1.0 & 1.1 & 1.1 & 1.2 & 1.1 & 1.0 & 1.0 & 1.0 & 1.1 & 1.1 & 1.1 & 1.2 & 1.0 \\
\hline Th & 0.1 & 9.8 & 11.1 & 11.1 & 12.5 & 10.7 & 10.2 & 10.7 & 9.8 & 10.8 & 12.4 & 12.6 & 11.7 & 10.4 \\
\hline $\mathrm{U}$ & 0.1 & 2.4 & 2.7 & 2.3 & 2.5 & 2.1 & 2.5 & 2.7 & 2.7 & 2.6 & 3.1 & 3.1 & 2.6 & 2.6 \\
\hline $\mathrm{La}$ & 0.1 & 29.8 & 32.5 & 32.6 & 34.7 & 30.9 & 29.8 & 29.5 & 27.1 & 29.5 & 30.5 & 30.8 & 30.7 & 28.4 \\
\hline $\mathrm{Ce}$ & 0.1 & 59.3 & 69.3 & 67.1 & 72.6 & 63.3 & 61.6 & 61.6 & 55.4 & 59.5 & 63.2 & 63.1 & 64.3 & 59.5 \\
\hline $\mathrm{Pr}$ & 0.05 & 7.16 & 8.03 & 7.90 & 8.43 & 7.42 & 7.35 & 7.33 & 6.82 & 7.17 & 7.42 & 7.26 & 7.45 & 6.83 \\
\hline $\mathrm{Nd}$ & 0.1 & 28.1 & 30.8 & 30.9 & 32.7 & 28.6 & 29.2 & 28.4 & 25.6 & 28.4 & 28.2 & 28.6 & 28.7 & 26.5 \\
\hline $\mathrm{Sm}$ & 0.1 & 5.8 & 6.6 & 6.4 & 6.7 & 6.0 & 6.2 & 5.8 & 5.4 & 5.7 & 5.6 & 5.8 & 5.7 & 5.2 \\
\hline $\mathrm{Eu}$ & 0.05 & 1.26 & 1.34 & 1.36 & 1.43 & 1.34 & 1.30 & 1.23 & 1.15 & 1.24 & 1.15 & 1.10 & 1.21 & 1.16 \\
\hline Gd & 0.1 & 5.3 & 5.7 & 5.7 & 5.8 & 5.2 & 5.2 & 5.1 & 4.7 & 4.9 & 4.7 & 4.9 & 5.1 & 4.8 \\
\hline $\mathrm{Tb}$ & 0.1 & 0.8 & 0.9 & 0.9 & 0.9 & 0.8 & 0.8 & 0.8 & 0.8 & 0.8 & 0.7 & 0.8 & 0.8 & 0.7 \\
\hline Dy & 0.1 & 4.8 & 5.2 & 5.0 & 5.5 & 4.8 & 4.9 & 4.7 & 4.5 & 4.6 & 4.6 & 4.6 & 4.8 & 4.5 \\
\hline Ho & 0.1 & 1.0 & 1.0 & 1.0 & 1.0 & 1.0 & 0.9 & 0.9 & 0.9 & 0.9 & 0.9 & 0.9 & 0.9 & 0.9 \\
\hline $\mathrm{Er}$ & 0.1 & 2.8 & 2.8 & 2.9 & 3.0 & 2.9 & 2.9 & 2.7 & 2.6 & 2.7 & 2.6 & 2.7 & 2.7 & 2.6 \\
\hline $\mathrm{Tm}$ & 0.05 & 0.41 & 0.44 & 0.44 & 0.44 & 0.43 & 0.43 & 0.40 & 0.39 & 0.40 & 0.40 & 0.40 & 0.40 & 0.39 \\
\hline $\mathrm{Yb}$ & 0.1 & 2.7 & 2.9 & 2.8 & 3.0 & 2.9 & 2.7 & 2.7 & 2.6 & 2.6 & 2.7 & 2.7 & 2.7 & 2.6 \\
\hline $\mathrm{Lu}$ & 0.04 & 0.43 & 0.45 & 0.45 & 0.47 & 0.43 & 0.42 & 0.41 & 0.40 & 0.41 & 0.40 & 0.42 & 0.40 & 0.39 \\
\hline$\Sigma$ REE & - & 149.6 & 167.4 & 165.4 & 176.67 & 156.0 & 153.7 & 151.6 & 138.4 & 148.8 & 153.1 & 154.8 & 155.9 & 144.5 \\
\hline $\mathrm{La}_{\mathrm{N}} / \mathrm{Y}_{\mathrm{N}}$ & - & 0.81 & 0.82 & 0.85 & 0.85 & 0.78 & 0.81 & 0.80 & 0.76 & 0.83 & 0.83 & 0.84 & 0.83 & 0.80 \\
\hline $\mathrm{Eu}_{\mathrm{N}} / \mathrm{Eu}_{\mathrm{N}}{ }^{*}$ & - & 1.07 & 1.03 & 1.06 & 1.08 & 1.13 & 1.08 & 1.06 & 1.07 & 1.10 & 1.05 & 0.97 & 1.05 & 1.09 \\
\hline $\mathrm{Ce}_{\mathrm{N}} / \mathrm{Ce}_{\mathrm{N}}{ }^{*}$ & - & 0.91 & 0.97 & 0.94 & 0.95 & 0.94 & 0.93 & 0.94 & 0.93 & 0.91 & 0.95 & 0.94 & 0.96 & 0.96 \\
\hline CIA & - & 61.1 & 63.5 & 64.3 & 68.6 & 61.5 & 59.2 & 59.6 & 56.5 & 60.2 & 59.1 & 56.8 & 62.5 & 59.2 \\
\hline CIW & - & 67.5 & 70.3 & 71.3 & 75.8 & 68.0 & 66.0 & 66.6 & 62.6 & 67.4 & 67.3 & 64.9 & 71.0 & 65.8 \\
\hline PIA & - & 50.1 & 52.2 & 52.7 & 57.4 & 50.4 & 46.9 & 46.7 & 44.6 & 47.1 & 45.3 & 43.3 & 49.1 & 47.2 \\
\hline LWI & - & 11.3 & 10.4 & 10.8 & 9.5 & 11. 8 & 13.2 & 13.0 & 15. 3 & 13.3 & 12.8 & 13.6 & 11.8 & 13.1 \\
\hline $\mathrm{Rb} / \mathrm{Sr}$ & - & 0.36 & 0.47 & 0.44 & 0.53 & 0.36 & 0.34 & 0.39 & 0.32 & 0.43 & 0.48 & 0.42 & 0.48 & 0.37 \\
\hline $\mathrm{CaO} / \mathrm{TiO}_{2}$ & - & 2.7 & 2.3 & 2.3 & 1.8 & 2.6 & 3.0 & 2.9 & 3.7 & 3.1 & 2.8 & 3.0 & 2.3 & 3.1 \\
\hline $\mathrm{Na}_{2} \mathrm{O} / \mathrm{TiO}_{2}$ & - & 3.0 & 2.6 & 2.6 & 2.2 & 3.0 & 3.2 & 3. 3 & 4.2 & 3.0 & 3.8 & 4. 5 & 3. 1 & 3.2 \\
\hline
\end{tabular}

$\mathrm{Eu}_{\mathrm{N}} / \mathrm{Eu}_{\mathrm{N}} *=\mathrm{Eu} /(\mathrm{Sm} * \mathrm{Gd})^{0.5}$ (McLennan, 1989).

$\mathrm{Ce}_{\mathrm{N}} / \mathrm{Ce}_{\mathrm{N}}{ }^{*}=\mathrm{Ce} /(1 / 3 \mathrm{Nd}+2 / 3 \mathrm{La})$ (Elderfield et al., 1990).

$\mathrm{N}$ denotes normalization to Upper Continental Crust (McLennan, 2001).

CIA: Chemical Index of Alteration; CIW: Chemical Index of Weathering; PIA: Plagioclase Index of Alteration; LWI: Loess Weathering Index.

a large lateral extension (in a north-south direction) and it disappears in the field where the cultivated neosol emerges. The neosol is characterized by the following horizons: Ap-Bw-BC-Ck; it is classified as Haplic Kastanozems (WRB, 2006; which corresponds to a Typical Haplustoll according to Soil Survey Staff, 2014), and belongs to Corralito series (Rouzaut et al., 2012b).

The mineralogical composition of the Pampean loess has been described by several authors. Argüello et al. (2010) characterized the bulk mineralogy of a Pampean loess profile (grain size with mode in the coarse silt fraction) located on the Tilted Platform, near the study area ( $\sim 55 \mathrm{~km}$ north of the studied Corralito I sequence), pointing out the presence of quartz and feldspars as dominant minerals, with calcite, muscovite, illite and hornblende as subordinate minerals. Chlorite is also present as a trace mineral, possibly due to the in situ degradation of biotite, hornblende and other ferromagnesian minerals. Volcanic-pyroclastic glass has been recognized in Pampean loess by several authors, 

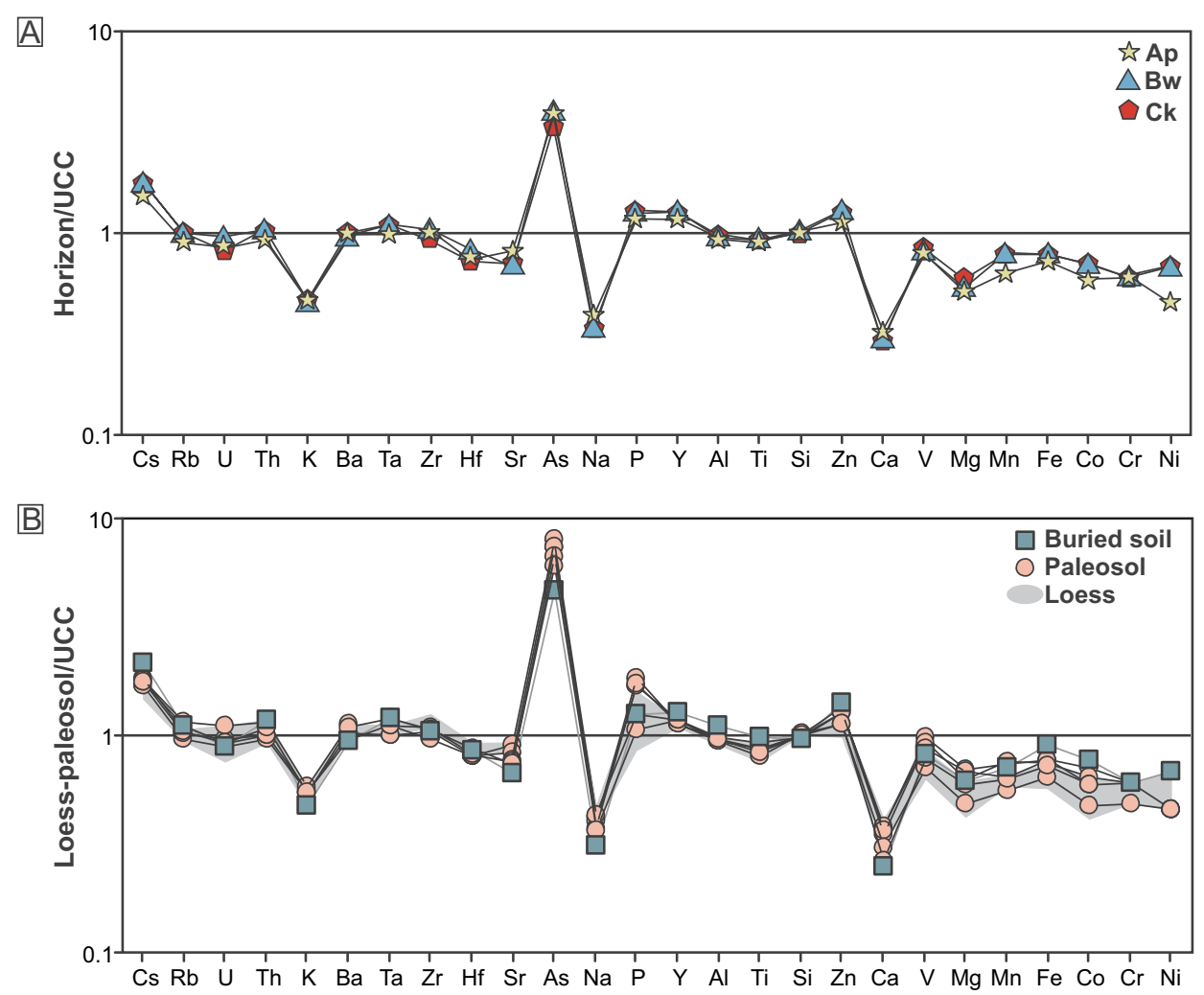

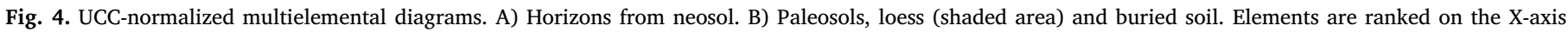
according to their progressive enrichment in the upper continental crust (UCC, McLennan, 2001) with respect to the Earth's primitive mantle (Hofmann, 1988).

such as Teruggi (1957), Nicolli et al. (2010), Argüello et al. (2012), and Rouzaut and Orgeira (2017). Other minerals identified in Pampean loess are hypersthene, enstatite, magnetite, hematite, ilmenite, zircon, monazite, apatite, Fe-oxides, Ti-oxides, Fe-Ti-oxides, and Fe-Mn oxides (Smedley et al., 2002; Etchichury and Tófalo, 2004; Nicolli et al., 2010). The clay fraction of the Pampean loess in the region is dominated by illite and smectite + expandable mixed layers, with trace amounts of kaolinite, quartz and feldspar.

The grain size and the calcium carbonate contents of Corralito I sequence (Fig. 3) were determined by Rouzaut et al. (2012a). The mean grain size ranges between 20 and $24 \mu \mathrm{m}$ (medium silt) in the paleosols and in the buried soil, while the mean particle diameter in the loess layers is slightly higher and varies between 25 and $35 \mu \mathrm{m}$ (medium to coarse silt). The calcium carbonate contents range between 0.2 and $6 \%$, and the loess mantles register the higher contents.

The pedological processes recognized in the sequence are melanization, decarbonation-carbonation (due to the presence of $\mathrm{CaCO}_{3}$ ) and clay illuviation. The clay illuviation process can be inferred in the paleosols by the presence of clay coatings on ped faces, which allowed to classify them as Bt horizons (Rouzaut et al., 2015). The neosol is under crop rotation, which has been soybean - corn - soybean during summer and wheat or barley in winter for the last 30 years.

Frechen et al. (2009) established, by means of luminescence methods, a Late Pleistocene - Holocene age for Corralito I sequence. An age of $115 \pm 21 \mathrm{ka}$ was estimated for loess III, whereas an age of $13.8 \pm 2.1$ ka was determined for B loess (Fig. 3).

The study area lies in Argentina's temperate zone. The current climate in the region is mesothermal, typically continental, with unevenly distribution of annual rainfall. Mean annual rainfall for the record period 1960-2015 is $815 \mathrm{~mm}$ (registered in Córdoba Aeropuerto gauging station, located approximately $100 \mathrm{~km}$ from Corralito I), which is mainly concentrated between November and April (wet season, $660 \mathrm{~mm}$ for the same record period). The mean annual temperature is $16.6^{\circ} \mathrm{C}$ for the record period $1960-2015$. As a consequence of its geographical location and climate, the region is subjected to a "weathering-limited" erosional regime in the sense of Carson and Kirkby (1972), as it was already pointed out by Campodonico et al. (2014), Pasquini et al. (2017), and references therein. In such erosional regimes, the transport of material is more rapid than weathering, and sediments derived from such areas are relatively unaltered, in contrast to "transport-limited" regimes, where weathering rates exceed the transport rates (e.g., Stallard and Edmond, 1983).

\section{Materials and methods}

\subsection{Samples and analytical determinations}

The loess-paleosol sequence can be considered as a sedimentarypedological succession and it was earlier described and sampled by Rouzaut et al. (2012a, 2012b, 2015), and Rouzaut and Orgeira (2017). In this work, 13 samples, from the base to the top of the sequence, were selected to determine elemental concentrations: three samples from the neosol, one from the buried soil, five from the paleosols, and four from loess mantles (Table 1 ).

All samples were air-dried, crushed and passed through a $2 \mathrm{~mm}$ sieve. Organic matter and carbonates were removed by conventional methods using hydrogen peroxide and acetic acid, respectively. Major oxides and trace elements, including rare earth elements, were determined at Activation Laboratories (ActLabs, Ontario, Canada). Major chemical composition and some trace elements, such as Sc, V, Ba, Sr, Y and $\mathrm{Zr}$, were measured by ICP-OES, whereas the remaining trace elements were determined by ICP-MS. For chemical analyses samples were mixed with a flux of lithium metaborate and lithium tetraborate in graphite crucibles and fused in an induction furnace at $1150{ }^{\circ} \mathrm{C}$. The molten melt was immediately poured into a solution of $5 \%$ nitric acid containing an internal standard, and mixed continuously until completely dissolved $(\sim 30 \mathrm{~min})$. One blank and 14 reference materials (NIST 694, DNC-1, LKSD-3, TDB-1, W-2a, SY-4, CTA-AC-1, BIR-1a, NCS 
A
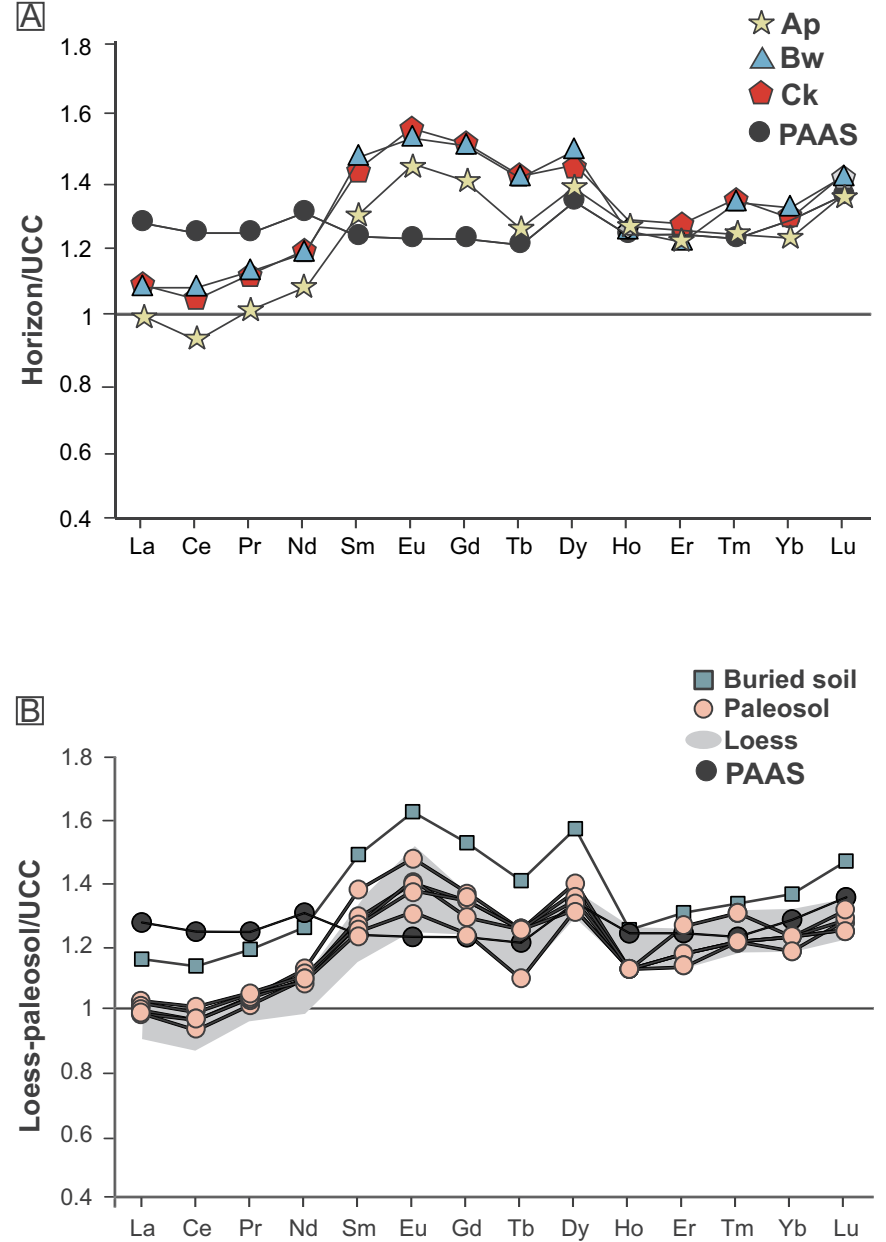

Fig. 5. UCC-normalized REE diagrams. A) Horizons from neosol. B) Paleosols, buried soil and loess (shaded area). The Y-axis has an arithmetic scale in order to easily identify the differences between the patterns. Post Archean Australian Shale (PAAS; McLennan, 1989) is included for comparison. Upper continental crust (UCC) composition from McLennan (2001).

DC86312, NCS DC70009, OREAS 100a, OREAS 101a, OREAS 101b, JR1) certified by the National Institute of Standards and Technology, the USGS, CANMET, the Institute of Nuclear Chemistry and Technology, The China National Analysis Center for Iron and Steel, the Ore Research and Exploration Pty Ltd. and the Geological Survey of Japan were analyzed. The accuracy of standard measures ranged between 1 and $10 \%$ in most cases. Furthermore, duplicated analyses were performed to check the reproducibility of results, and the precision was $<10 \%$ for all the analyzed elements.

\subsection{Weathering assessment}

Numerous chemical alteration indices and elemental ratios have been defined in the literature and are widely employed to assess weathering (e.g., Price and Velbel, 2003; Depetris et al., 2014). Some of these indices were calculated in the Corralito I loess-paleosol sequence in order to assess the degree of weathering of such deposits. The Chemical Index of Alteration (CIA; Nesbitt and Young, 1982) is one of the most extensively used indices to estimate weathering intensity. It is defined as:

$\mathrm{CIA}=100\left[\mathrm{Al}_{2} \mathrm{O}_{3} /\left(\mathrm{Al}_{2} \mathrm{O}_{3}+\mathrm{CaO}^{*}+\mathrm{Na}_{2} \mathrm{O}+\mathrm{K}_{2} \mathrm{O}\right)\right]$

where oxides are in molar proportions and $\mathrm{CaO} *$ represents the $\mathrm{Ca}$ in the silicate fraction only, adjusted for some other Ca-bearing minerals such as apatite and carbonates. Since carbonates were previously

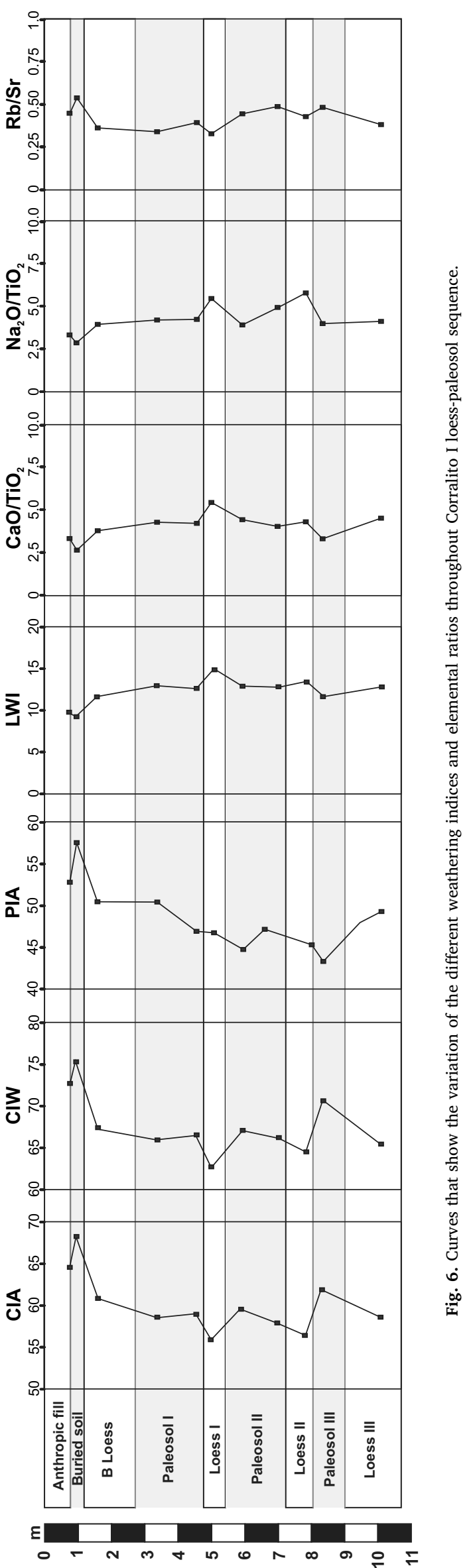




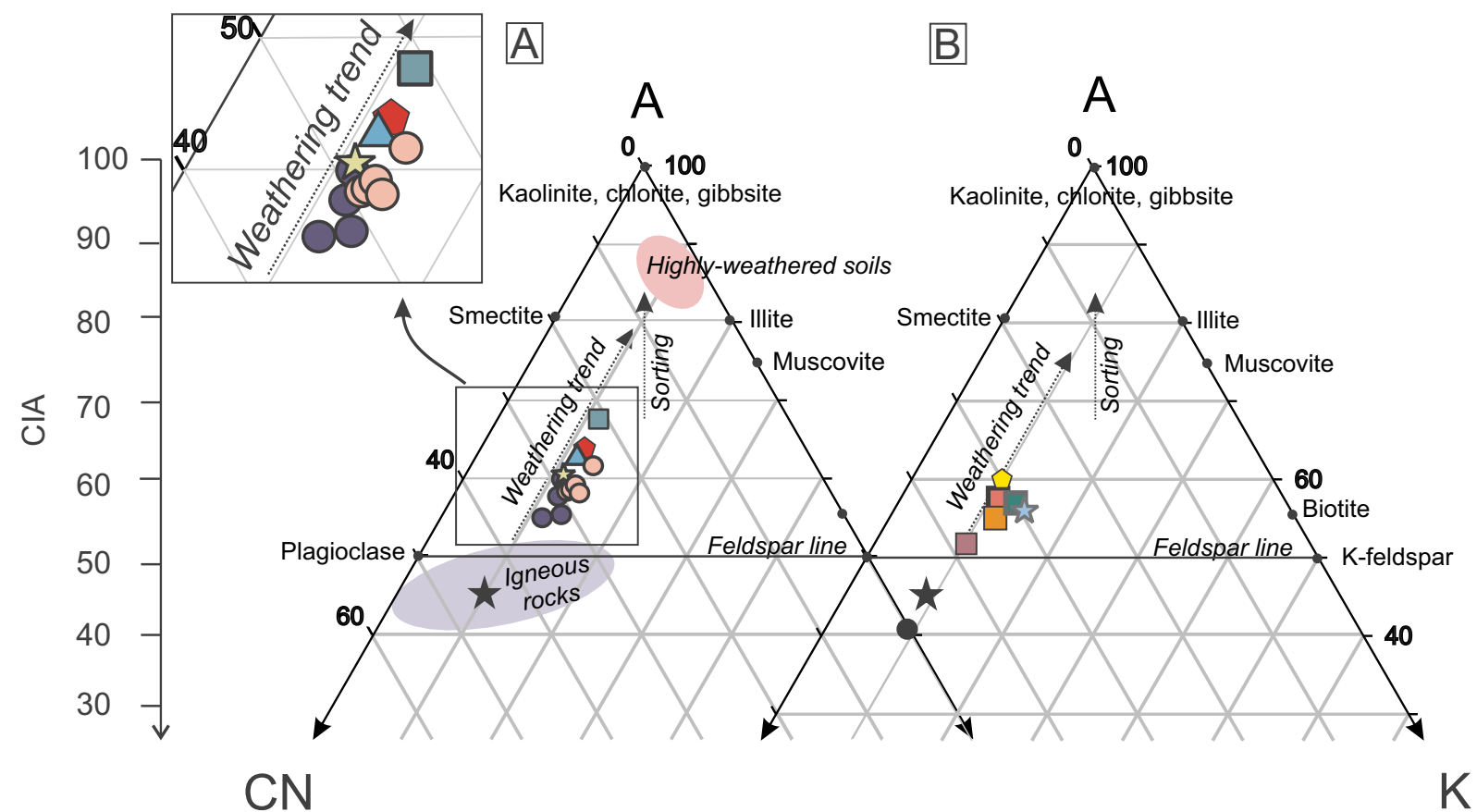

\begin{tabular}{|ll|}
\hline REFERENCES & $\square$ Ancasti range loess \\
$\star$ Ap-horizon Neosol & $\square$ Corralito loess \\
$\triangle$ Bw-horizon Neosol & $\square$ Sierra Chica loess \\
$\square$ Ck-horizon Neosol & Tucumán loess \\
$\square$ Buried soil & $\star$ Pampean loess \\
0 Loess & $\square$ Buenos Aires loess \\
$\bigcirc$ Paleosol & $\square$ GAL \\
$\star$ UCC &
\end{tabular}

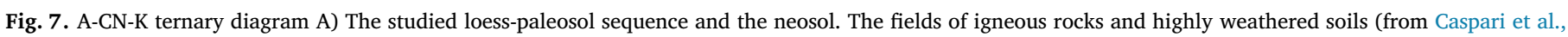

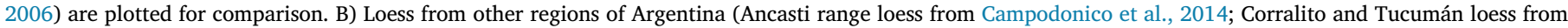

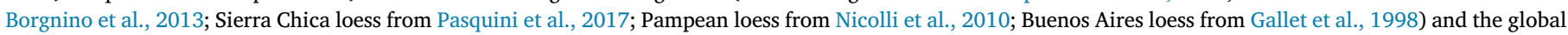

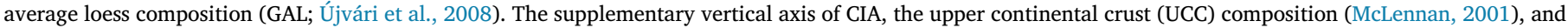
the theoretical weathering and sorting trends are also included.

removed from the samples, we applied here the correction for apatite, using the concentrations of $\mathrm{P}_{2} \mathrm{O}_{5}$ as it was proposed by McLennan (1993). CIA values of 45 to 55 indicate practically no weathering as the upper continental crust (UCC) has a CIA of $\sim 47$ (McLennan, 1993), whereas highly weathered materials have CIAs $>80$. Clay minerals such as smectite and illite exhibit CIAs of $\sim 80$, while kaolinite shows CIAs close to 100 .

Another index similar to CIA is the Chemical Index of Weathering (CIW) proposed by Harnois (1988), which does not consider potassium because it may be adsorbed onto clays through ion exchange during chemical alteration and is defined as follows:

$\mathrm{CIW}=100\left[\mathrm{Al}_{2} \mathrm{O}_{3} /\left(\mathrm{Al}_{2} \mathrm{O}_{3}+\mathrm{CaO}+\mathrm{Na}_{2} \mathrm{O}\right)\right]$

Like CIA, increasing CIW values indicate progressively more altered materials (i.e., smectite $\mathrm{CIW}=80$; kaolinite $\mathrm{CIW}=100$ ).

The Plagioclase Index of Alteration (PIA) was proposed by Fedo et al. (1995) as an alternative to the CIA. This index is used to examine plagioclase weathering, which is abundant in silicate rocks and dissolves relatively rapidly. It is calculated as follows:

PIA $=100\left[\left(\mathrm{Al}_{2} \mathrm{O}_{3}-\mathrm{K}_{2} \mathrm{O}\right) /\left(\mathrm{Al}_{2} \mathrm{O}_{3}+\mathrm{CaO}^{*}+\mathrm{Na}_{2} \mathrm{O}+\mathrm{K}_{2} \mathrm{O}\right)\right]$

where $\mathrm{CaO} *$ representes the $\mathrm{Ca}$ in the silicate fraction only. Fresh rocks exhibit PIA values of $\sim 50$, whereas clay minerals such as kaolinite, illite, and gibbsite show values close to 100 , consistent with values derived from the CIA equation (Fedo et al., 1995).
Yang et al. (2006) proposed the Loess Weathering Index (LWI), a proxy for chemical weathering intensity of loess deposits. This index is not influenced by grain size and higher values indicate lower chemical weathering intensity. It is calculated as follows:

$\mathrm{LWI}=\left[\left(\mathrm{CaO}+\mathrm{Na}_{2} \mathrm{O}+\mathrm{MgO}\right) / \mathrm{TiO}_{2}\right]$

Likewise, elemental ratios such as $\mathrm{Rb} / \mathrm{Sr}, \mathrm{CaO} / \mathrm{TiO}_{2}$ and $\mathrm{Na}_{2} \mathrm{O} / \mathrm{TiO}_{2}$ have been extensively used to analyze chemical weathering (e.g., Chen et al., 2001; Muhs et al., 2001; Buggle et al., 2011; Ahmad and Chandra, 2013; Újvári et al., 2014). Ca, Na and Sr are common in silicate minerals susceptible to chemical attack such as plagioclase, pyroxene and amphibole (e.g., Nesbitt et al., 1980; Scott, 2009). Regarding the choice of immobile elements, ions that have large ionic radius and can be immobilized by adsorption onto clay minerals, such as $\mathrm{Rb}$, can be employed when incipient to moderate weathering conditions prevail (e.g., Buggle et al., 2011). Other elements usually used in weathering proxies are those of the "insoluble hydrolyzate" category such as $\mathrm{Ti}$ (e.g., Muhs et al., 2001). These ratios, where the concentrations of soluble compounds are normalized to immobile elements, have been calculated for the studied loess-paleosol sequence.

Several ternary diagrams have also been proposed to assess the extent of chemical weathering (e.g., Nesbitt et al., 1996). One of the most commonly applied is the $\mathrm{Al}_{2} \mathrm{O}_{3}-\left(\mathrm{CaO} *+\mathrm{Na}_{2} \mathrm{O}\right)-\mathrm{K}_{2} \mathrm{O}$ ternary diagram (A-CN-K diagram), where oxides are in molar proportions and $\mathrm{CaO}^{*}$ represents the $\mathrm{CaO}$ in the silicate fraction only. In this diagram, 
Table 2

Mass balance changes in major oxides and selected trace elements that each loess layer undergoes when compared to its overlying paleosol layer.

\begin{tabular}{|c|c|c|c|c|c|c|}
\hline & \multicolumn{6}{|c|}{ Gain $(+)$ or loss $(-) \%$} \\
\hline & \multirow{2}{*}{$\frac{\text { Buried soil }}{\text { CORI BS }}$} & \multicolumn{2}{|l|}{ Paleosol I } & \multicolumn{2}{|l|}{ Paleosol II } & \multirow{2}{*}{$\frac{\text { Paleosol III }}{\text { CORI PIII }}$} \\
\hline & & CORI PI-1 & CORI PI-2 & CORI PII-1 & CORI PII-2 & \\
\hline \multicolumn{7}{|c|}{ Major oxides } \\
\hline $\mathrm{SiO}_{2}$ & -8.27 & -15.46 & -8.91 & -16.58 & -6.68 & 5.73 \\
\hline $\mathrm{Al}_{2} \mathrm{O}_{3}$ & 5.00 & -9.17 & -6.85 & -7.14 & -0.97 & 7.75 \\
\hline $\mathrm{Fe}_{2} \mathrm{O}_{3(\mathrm{~T})}$ & 14.64 & 0.05 & 3.33 & 17.98 & 5.84 & 4.23 \\
\hline $\mathrm{MnO}$ & 2.96 & 3.81 & 10.23 & -2.49 & -8.28 & 0.67 \\
\hline $\mathrm{MgO}$ & -1.94 & 5.29 & 1.04 & 40.68 & 10.30 & 0.84 \\
\hline $\mathrm{CaO}$ & -30.15 & -20.11 & -21.79 & 3.26 & -6.59 & -26.84 \\
\hline $\mathrm{Na}_{2} \mathrm{O}$ & -27.69 & -23.02 & -21.23 & -32.08 & -14.38 & -2.67 \\
\hline $\mathrm{K}_{2} \mathrm{O}$ & -5.72 & -9.83 & -4.26 & -15.71 & -2.97 & 13.86 \\
\hline $\mathrm{TiO}_{2}$ & 0.00 & 0.00 & 0.00 & 0.00 & 0.00 & 0.00 \\
\hline $\mathrm{P}_{2} \mathrm{O}_{5}$ & -8.55 & -8.34 & 5.43 & 79.63 & 41.63 & -21.52 \\
\hline \multicolumn{7}{|c|}{ Trace elements } \\
\hline Sc & 16.08 & 1.02 & 6.20 & 13.12 & 3.80 & 4.00 \\
\hline $\mathrm{V}$ & -8.79 & 2.15 & 0.23 & 20.78 & 7.04 & -2.93 \\
\hline $\mathrm{Ba}$ & -15.18 & -17.45 & -11.80 & -26.93 & -6.39 & 12.87 \\
\hline $\mathrm{Sr}$ & -26.68 & -15.27 & -17.91 & -17.87 & -12.26 & -6.44 \\
\hline As & -26.64 & -4.76 & 9.23 & -4.29 & -5.63 & 4.00 \\
\hline $\mathrm{Y}$ & 1.57 & -9.95 & -8.97 & -16.33 & -5.63 & 12.67 \\
\hline $\mathrm{Zr}$ & -11.47 & -15.54 & -11.65 & -32.98 & -16.48 & -1.35 \\
\hline $\mathrm{Cr}$ & -5.68 & 8.23 & 13.78 & 8.77 & -5.63 & 4.00 \\
\hline Co & 11.47 & 3.90 & 0.13 & 24.30 & 7.85 & -5.45 \\
\hline $\mathrm{Ni}$ & -5.68 & -13.41 & -8.97 & -99.57 & 0.00 & -30.67 \\
\hline $\mathrm{Zn}$ & 17.90 & -2.59 & 2.40 & 11.87 & 7.85 & -7.56 \\
\hline $\mathrm{Rb}$ & 10.18 & -11.77 & -1.17 & -15.16 & 0.66 & 19.41 \\
\hline Cs & 22.86 & 0.80 & 10.05 & 4.17 & 8.99 & 13.84 \\
\hline $\mathrm{Hf}$ & -11.12 & -17.02 & -12.77 & -25.88 & -17.87 & 6.12 \\
\hline $\mathrm{Ta}$ & 2.89 & -13.41 & -8.97 & -12.99 & -5.63 & 24.80 \\
\hline Th & 10.18 & -9.88 & -0.61 & -25.42 & -7.13 & 17.00 \\
\hline $\mathrm{U}$ & 12.28 & -19.83 & -8.97 & -27.02 & -5.63 & 4.00 \\
\hline $\mathrm{La}$ & 5.92 & -4.79 & -0.91 & -16.66 & -6.55 & 12.42 \\
\hline $\mathrm{Ce}$ & 8.18 & -3.72 & 1.21 & -17.95 & -5.48 & 12.39 \\
\hline $\operatorname{Pr}$ & 7.16 & -6.69 & -2.17 & -14.07 & -3.55 & 13.44 \\
\hline $\mathrm{Nd}$ & 7.84 & -1.24 & 0.98 & -13.60 & -6.95 & 12.63 \\
\hline $\mathrm{Sm}$ & 5.32 & -0.59 & -2.23 & -14.49 & -8.89 & 14.00 \\
\hline $\mathrm{Eu}$ & 0.65 & -2.12 & -2.64 & -1.91 & -1.34 & 8.48 \\
\hline $\mathrm{Gd}$ & 5.20 & -4.20 & -1.23 & -12.99 & -9.49 & 10.50 \\
\hline $\mathrm{Tb}$ & 6.11 & -13.41 & -8.97 & -12.99 & -17.43 & 18.86 \\
\hline Dy & 8.07 & -5.72 & -4.93 & -12.99 & -5.63 & 10.93 \\
\hline Ho & -5.68 & -13.41 & -8.97 & -12.99 & -5.63 & 4.00 \\
\hline $\mathrm{Er}$ & -2.43 & -3.42 & -5.47 & -12.99 & -9.13 & 8.00 \\
\hline $\mathrm{Tm}$ & -3.49 & -4.53 & -6.64 & -12.99 & -5.63 & 6.67 \\
\hline $\mathrm{Yb}$ & -2.43 & -10.08 & -5.47 & -16.21 & -5.63 & 8.00 \\
\hline $\mathrm{Lu}$ & 3.09 & -9.09 & -6.70 & -15.06 & -10.13 & 6.67 \\
\hline
\end{tabular}

the theoretical compositions of plagioclase and K-feldspar plot at $50 \%$ of the A apex, defining a "feldspar line" that represents the initial path to weathering. Instead, the theoretical composition of some clay mineral groups, such as kaolinite, gibbsite and chlorite plot at the A apex, whereas smectite and illite fall at $\sim 75 \%$ of the A apex (Nesbitt et al., 1996). The A-CN-K diagram is used here to infer the weathering trend in the loess-paleosol sequence.

The mobility of elements during chemical weathering can be assessed by means of mass balance calculations. Mass balance interpretations have been applied for quantifying the mobility of elements in loess-paleosol sequences (e.g., Yang et al., 2006; Sun et al., 2018) as well as in other environments and materials (e.g., Girty et al., 2003; Campodonico et al., 2014; Girty et al., 2014; Campodonico et al., 2019). The Woronow and Love (1990) log-ratio technique was employed here to quantify the elemental fractionation and mass changes that occurred between loess and paleosols. In this method each loess layer composition is assumed to be the initial composition of the overlaying paleosol, and the change in mass of any component relative to the mass of one immobile component is estimated. In this case, the $\mathrm{TiO}_{2}$ was used as a framework oxide. By means of Eq. (5) it can be estimated if the mass of each element has been enriched $(f>1$ ), depleted ( $f<1$ ) or experienced no change $(f=1)$ relative to its unaltered mass.

$\ln \mathrm{f}(\mathrm{m})=\left[\ln \left(\mathrm{x}^{\prime} \mathrm{m} / \mathrm{x}^{\prime} 1 \mathrm{~m}\right)\right]-[\ln (\mathrm{xm} / \mathrm{x} 1 \mathrm{~m})]$

where $\mathrm{x}^{\prime} \mathrm{m}$ is the mobile element in paleosol, $\mathrm{xm}$ is the mobile element in loess, $\mathrm{x}^{\prime} 1 \mathrm{~m}$ is the immobile element in paleosol and $\mathrm{x} 1 \mathrm{~m}$ is the immobile element in loess.

The percentage change in mass of an element $\mathrm{m}$ can be estimated according to Eq. (6).

$\Delta \%$ mass $=100\left(\mathrm{e}^{\ln (\mathrm{fm})}-1\right)$

\section{Results and discussion}

\subsection{Geochemistry of Corralito I sequence}

The concentrations of major, trace and rare earth elements (REE) measured in the loess-paleosol sequence and in the neosol, as well as several geochemical parameters, are shown in Table 1 .

The distribution of major and trace elements in the neosol and in the loess-paleosol sequence is shown in the upper continental crust (UCC; 


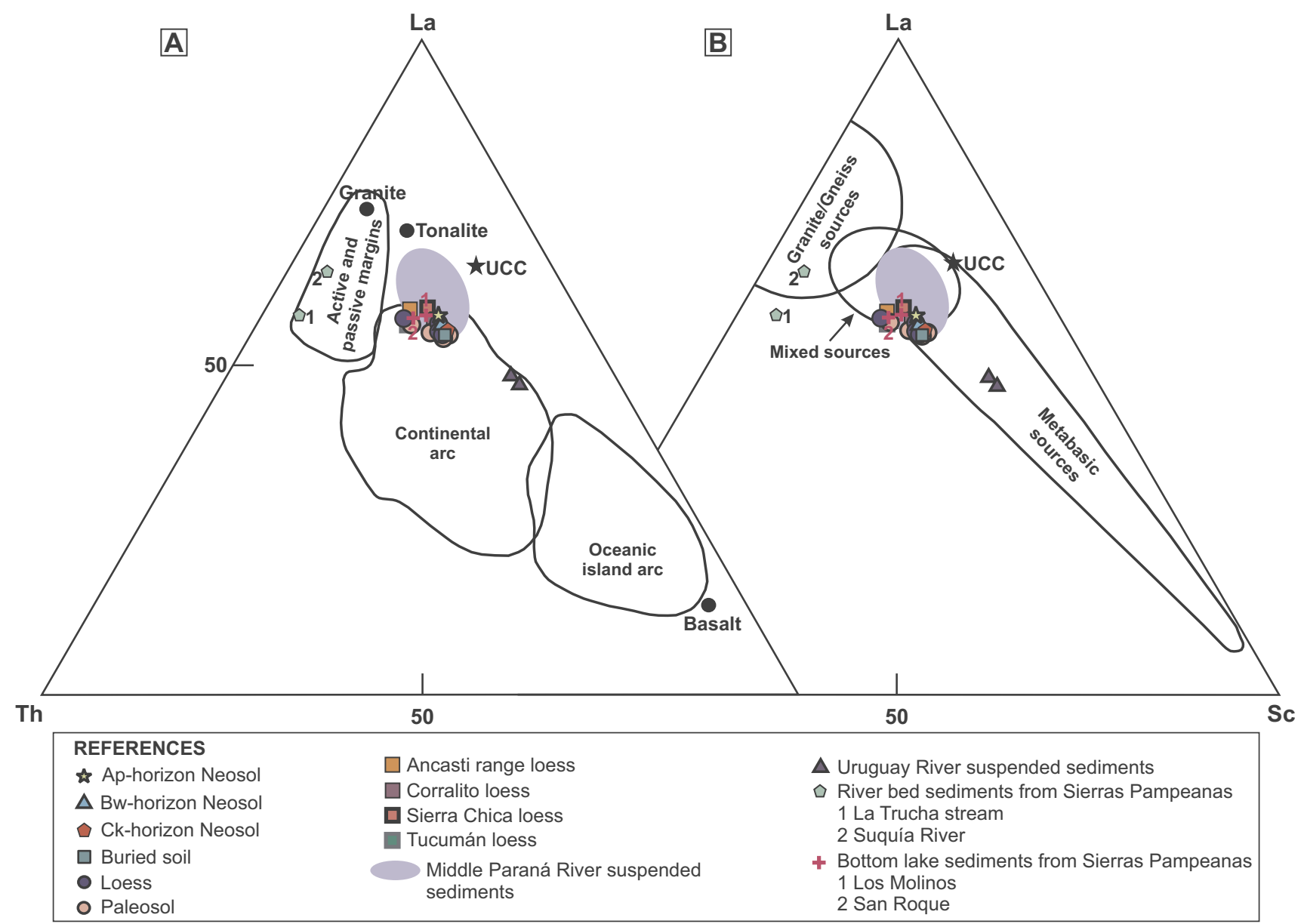

Fig. 8. La-Th-Sc compositional ternary diagrams showing A) the tectonic setting composition and B) sources of Corralito I loess-paleosol sequence. Other loess from Argentina (Ancasti range loess from Campodonico et al., 2014; Corralito and Tucumán loess from García, personal communication; Sierra Chica loess from Pasquini et al., 2017) are included for comparison. Suspended sediments from the Middle Paraná (Campodonico et al., 2016; Depetris and Pasquini, 2007) and Uruguay (Depetris and Pasquini, 2007) rivers, as well as river bed sediments (La Trucha stream after Campodonico et al., 2014; Suquía River after Sepúlveda et al., 2019) and bottom lake sediments (Bertolino et al., 2007) from Sierras Pampeanas, are also plotted as several authors considered that they constitute local Pampean loess sources. Compositional fields are from Bathia and Crook (1986) for the left triangle, and from Cullers (1994) for the right one.

McLennan, 2001) normalized extended diagrams (Fig. 4). The extended patterns of the neosol and the loess-paleosol sequence are quite similar, suggesting that the chemical composition of loess has not been substantially modified and pedogenesis has not been intense enough to mask the chemical signature of the parent material.

$\mathrm{Ca}, \mathrm{Na}, \mathrm{K}$ and $\mathrm{Sr}$ are depleted in the neosol and the loess-paleosol sequence with respect to the UCC, which reflects, in general, the weathering of feldspars (Fig. 4A and B). Fe, Mg, Mn, V, Co, Cr, and $\mathrm{Ni}$ are also depleted when compared to the UCC, likely due to the alteration of ferromagnesian minerals such as pyroxenes and amphiboles. Conversely, the neosol and the loess-paleosol sequence are enriched in Cs, As, P, Y and Zn (Fig. 4A and B). The UCC-enrichment of As is a feature inherited from the parent material as it was already pointed out by Pasquini et al. (2017). There is an agreement that the elevated concentrations of As are derived from the alteration of volcanic glass contained in the Pampean loess (e.g., Smedley et al., 2002; Nicolli et al., 2010). Recently, Bia et al. (2017) identified that the dominant As species in loess sediments from the Pampean plain was As(V) adsorbed onto $\mathrm{Fe}$ oxy(hidr)oxides, which are secondary minerals formed by chemical alteration of iron-bearing silicates. The slight enrichment in Cs and $\mathrm{Zn}$ indicates that these trace elements are possibly adsorbed onto clays (e.g., Bostick et al., 2002; Scott, 2009). The enrichment in P and Y probably reflects the presence of apatite in the neosol and the loesspaleosol sequence. $\mathrm{Y}$ is a common substituent for $\mathrm{Ca}$ in apatite (e.g.,

\section{Scott, 2009).}

The REEs are moderately mobile during chemical weathering depending on the weathering conditions and the stability of REE-bearing minerals (e.g., Nesbitt, 1979; Braun et al., 1990, 1998). In the absence of extreme chemical weathering, the mineralogical composition of the parent material mainly controls the REE content of soils (Laveuf and Cornu, 2009). The UCC-normalized REE diagrams for the present soil and the loess-paleosol sequence are shown in Fig. 5. The Post-Archean Australian Shale (PAAS; McLennan, 1989) is also included for comparison. It can be seen that the loess-paleosol sequence has basically similar patterns, which are also comparable with the distribution of REE in the neosol. The UCC-normalized REE diagram (Fig. 5A and B) shows a slight enrichment in middle (MREE; from Nd to $\mathrm{Tb}$ ) and heavy (HREE; from Dy to Lu) rare earth elements when compared to the UCC. This suggests that the light rare earth elements (LREEs) were removed during weathering, or that the source rock composition controls the REE signature. The HREEs enrichment $\left(\mathrm{La}_{\mathrm{N}} / \mathrm{Yb}_{\mathrm{N}}<1\right.$, where $\mathrm{N}$ denotes UCC normalization; Table 1 ) is likely associated with the presence of heavy minerals such as zircon, which is rather stable during weathering, whereas the high MREE content could be due to the occurrence of phosphate minerals (e.g., Hannigan and Sholkovitz, 2001) or Fe-Mn oxy-hydroxides (e.g., Johanesson and Zhou, 1999) in the soils. Fe-Mn oxides have been observed in the Pampean loess by Nicolli et al. (2010) and Bia et al. (2017). A similar distribution of REE was recognized by 


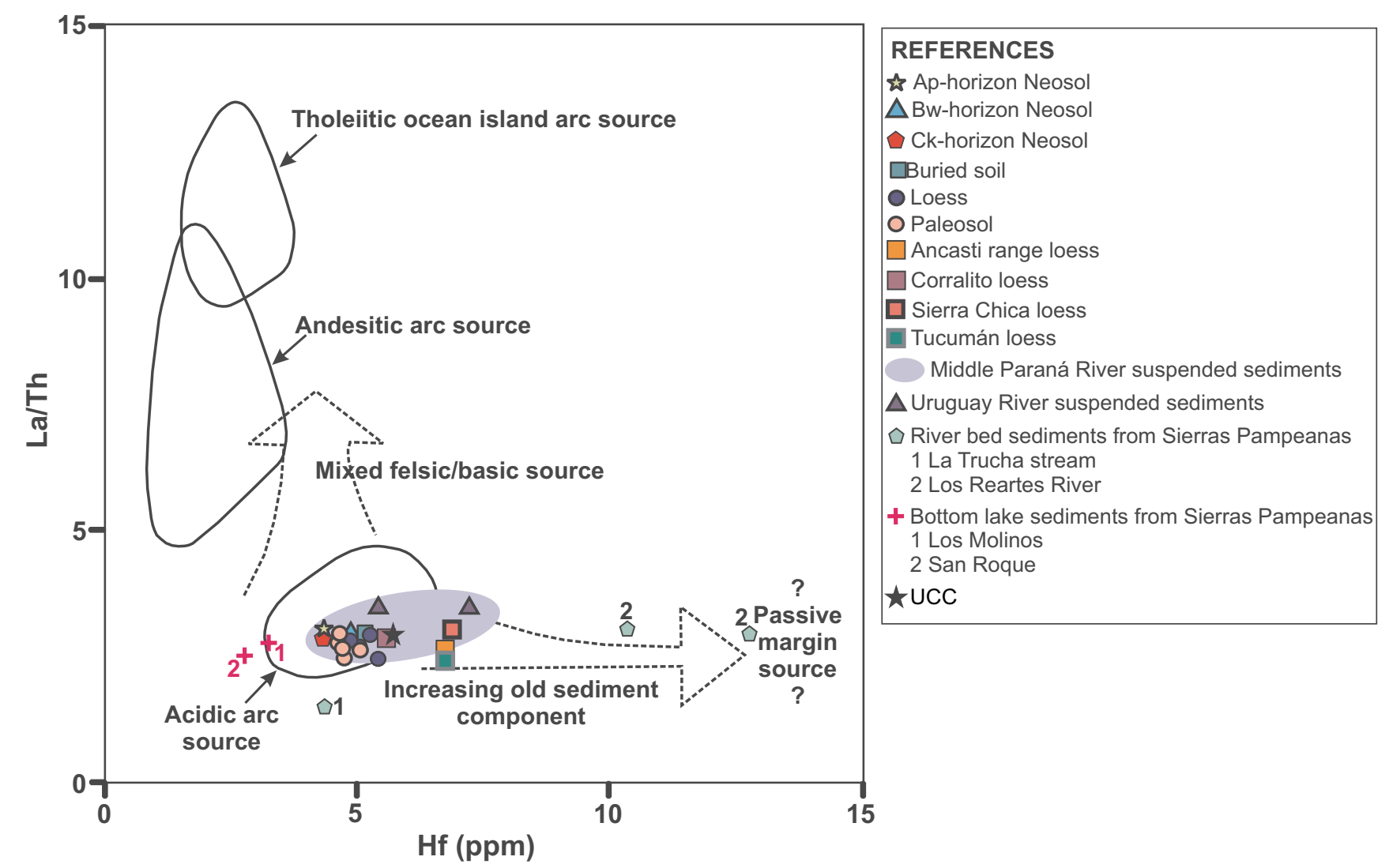

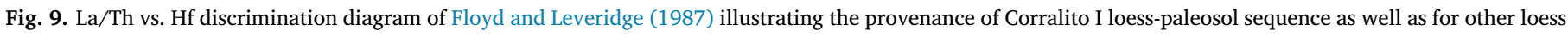

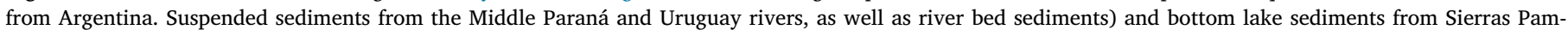
peanas, are also plotted. See references in Fig. 8. Los Reartes River bed sediments are from Pasquini et al. (2004).

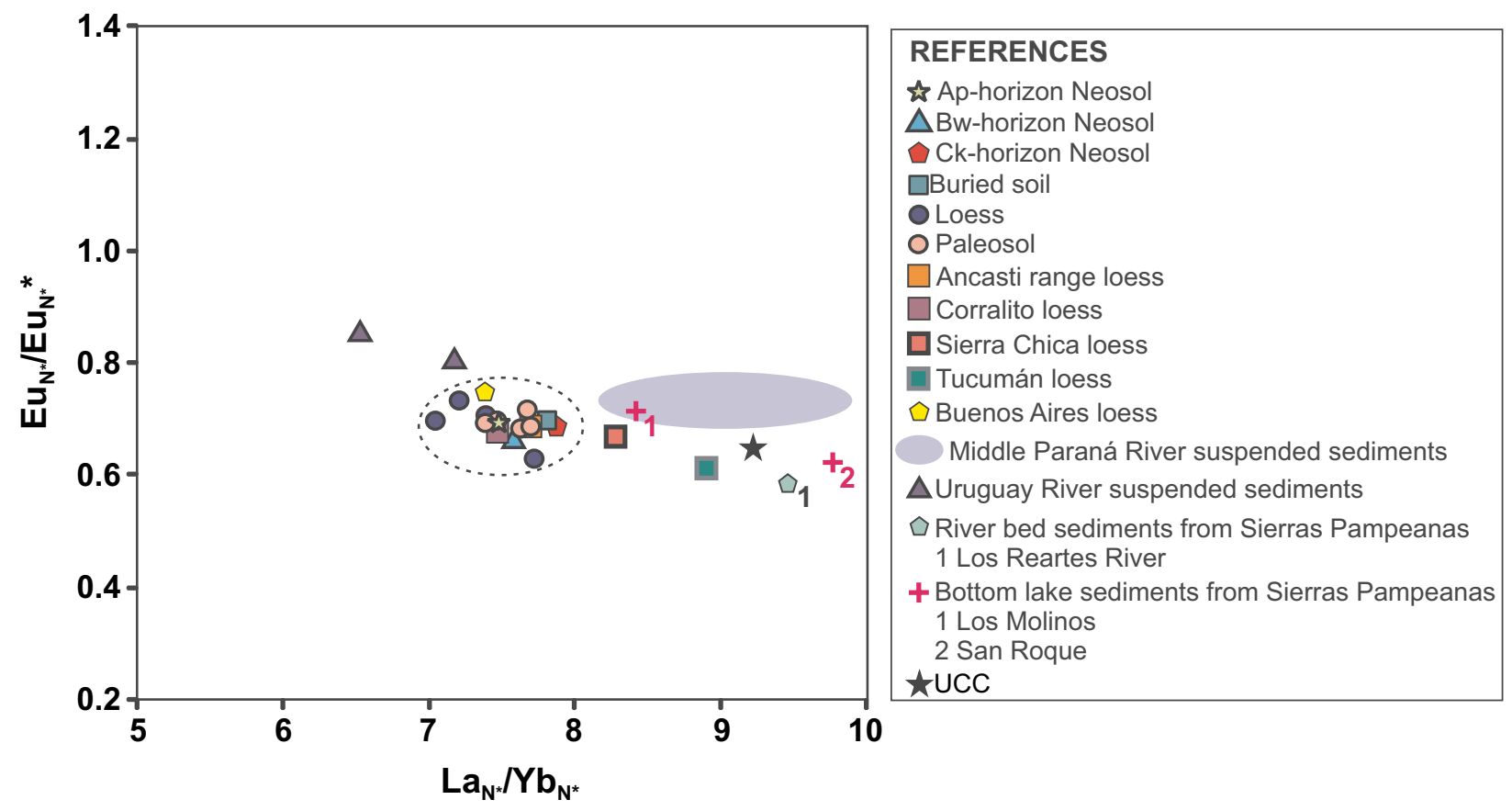

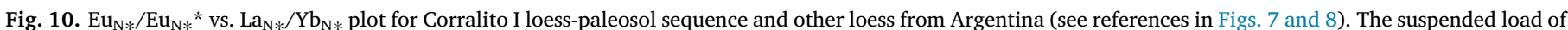

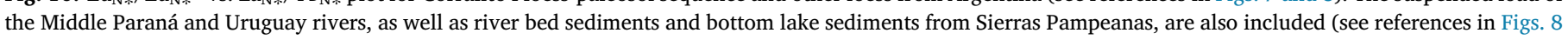
and 9). $\mathrm{N}^{*}$ denotes normalization to chondrite (Taylor and McLennan, 1985). 

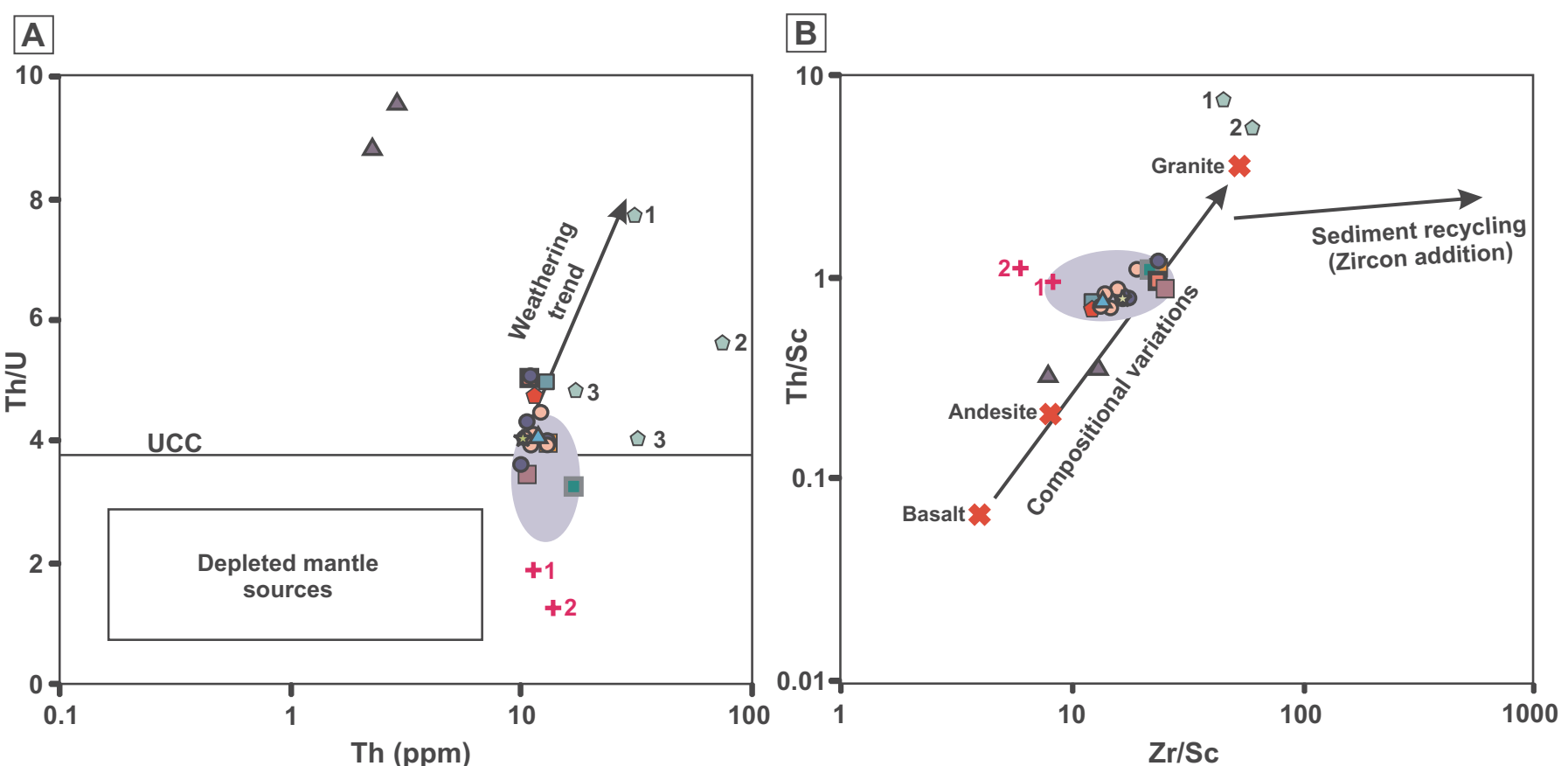

\begin{tabular}{|ll|}
\hline REFERENCES & Middle Paraná River suspended sediments \\
$\star$ Ap-horizon Neosol & $\Delta$ Uruguay River suspended sediments \\
$\Delta$ Bw-horizon Neosol & $\Delta$ River bed sediments from Sierras Pampeanas \\
$\square$ Ck-horizon Neosol & 1 La Trucha stream \\
$\square$ Buried soil & 2 Suquía River \\
OLoess & 3 Los Reartes River \\
O Paleosol & + Bottom lake sediments from Sierras Pampeanas \\
$\square$ Ancasti range loess & 1 Los Molinos \\
$\square$ Corralito loess & 2 San Roque \\
$\square$ Sierra Chica loess & \\
$\square$ Tucumán loess & \\
\hline
\end{tabular}

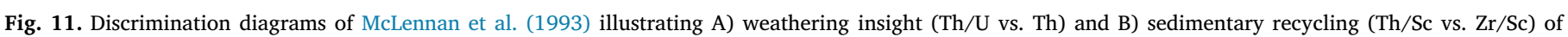

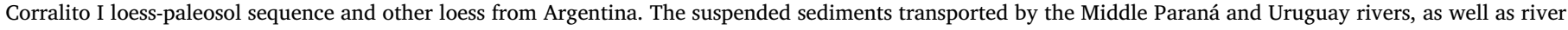

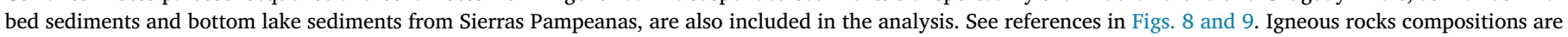
average values from Condie (1993).

Pasquini et al. (2017) in modern soils developed in loessic sediments in the piedmont of Sierra Chica de Córdoba (Argentina), which suggests that the parent material is controlling the REE contents in this section and that pedogenesis has not produced significant fractionation. It is interesting to note that the buried soil exhibits a slightly more enriched REE pattern when compared to the paleosols (Fig. 5B). Laveuf and Cornu (2009) pointed out that a significant amount of REE can be incorporated into soils by anthropogenic sources. Considering that the buried soil is covered by a layer of anthropogenic landfill, it is possible that the higher concentration of REEs comes from this source. On the other hand, the analyzed sequence does not show significant Eu and Ce anomalies $\left(\mathrm{Eu}_{\mathrm{n}} / \mathrm{Eu}_{\mathrm{n}}{ }^{*}=0.97-1.15 ; \quad \mathrm{Ce}_{\mathrm{n}} / \mathrm{Ce}_{\mathrm{n}}{ }^{*}=0.90-0.97 ; \quad\right.$ both anomalies were normalized to the UCC; Table 1).

\subsection{Weathering signature}

Weathering indices calculated for Corralito I sequence (Table 1) denote incipient chemical alteration throughout the analyzed loesspaleosol sequence. The CIA values are in agreement with the CIAs (CIA $=53$ to 70 ) of the worldwide compiled loess samples of Gallet et al. (1998). CIA values of the neosol (61-64) are slightly higher than those of the paleosols $(\sim 60)$ and loess $(\sim 58)$. The buried soil exhibits the highest value ( $\mathrm{CIA}=68$ ), suggesting moderate weathering. The variation of the different weathering indices and ratios along the loesspaleosol sequence is shown in Fig. 6. The CIW, PIA and LWI, as well as the ratios $\mathrm{CaO} / \mathrm{TiO}_{2}, \mathrm{Na}_{2} \mathrm{O} / \mathrm{TiO}_{2}$ and $\mathrm{Rb} / \mathrm{Sr}$ show, as expected, similar results than CIA (Table 1, Fig. 6) revealing a greater alteration of plagioclases in the paleosols when compared to loess mantles.

The ternary plots (A-CN-K) for the studied loess-paleosol sequence, the present soil, and other loess from Argentina are shown in Fig. 7. In the left triangle the field of igneous rocks, the UCC composition and highly weathered soils (Caspari et al., 2006) are plotted as a reference. Accordingly with the calculated weathering indices, Fig. 7A shows that the loess and paleosols of Corralito I exhibit an incipient degree of chemical alteration, i.e., an early $\mathrm{Ca}$ and $\mathrm{Na}$ removal stage, as the weathering trend is parallel to the A-CN line in the plot and close to the feldspar line. The neosol shows a similar behavior whereas, as it was pointed out above, the buried soil shows evidence of higher degree of chemical alteration (Fig. 7A). Furthermore, paleosols cluster around loess samples from this study and from other regions of Argentina (Fig. 7B), indicating that the incipient weathering signature of the paleosols resembles that of the loessic sediments. Conversely, the Global Average Loess composition (GAL, Újvári et al., 2008) plots in the field of unaltered materials, with a CIA value of $\sim 40$ (Fig. 7B).

Mass balance calculations were performed to better quantify the relative gains and losses of major oxides and selected trace elements experienced by paleosol layers compared to its loess mantle (Table 2). In general, the buried soil and paleosols I and II show losses in $\mathrm{CaO}$, $\mathrm{Na}_{2} \mathrm{O}, \mathrm{K}_{2} \mathrm{O}$, Sr and $\mathrm{Ba}$, reflecting the weathering of feldspars in these levels. Although paleosol III also exhibits losses in $\mathrm{CaO}, \mathrm{Na}_{2} \mathrm{O}$ and $\mathrm{Sr}$ 
reveling the chemical alteration of plagioclase, it shows relative gains of $\mathrm{K}_{2} \mathrm{O}$ and $\mathrm{Ba}$ suggesting that $\mathrm{K}$-feldspar is concentrated in this level compared to its loess mantle. In paleosols, $\mathrm{Fe}_{2} \mathrm{O}_{3}$ and $\mathrm{MgO}$ relative gains are recorded, indicating that ferromagnesian minerals such as pyroxenes and amphiboles or Fe oxy-hydroxides are concentrated in these levels. The buried soil also registers relative gains of $\mathrm{Fe}_{2} \mathrm{O}_{3}$. Cs, which is likely associated with clays (e.g., Bostick et al., 2002; Scott, 2009) exhibits relative gains at all levels. Regarding U, Th, and REE behavior, the relative losses registered in paleosols I and II, reveal that zircon and monazite, which are likely the host minerals of these elements, are preferentially retained in loess I and II. Conversely, the relative gains of $\mathrm{U}$, Th and REE in the buried soil and paleosol III are probably suggesting that these resistant minerals (i.e., zircon and monazite) are preferentially concentrated in these levels when compared to B loess and loess III. Finally, As exhibits relative losses in almost all levels, evidencing the chemical alteration of volcanic glass.

\subsection{Provenance}

Several compositional diagrams have been proposed in the literature to determine the relationship between geochemical composition, provenance and tectonic setting (e.g., Bathia, 1983; Roser and Korsch, 1986; Floyd and Leveridge, 1987). Such diagrams have been widely used to constrain the provenance of sediments and sedimentary rocks, but also of atmospheric dust, soils and loess-paleosol sequences (e.g., Sun et al., 2006; Muhs and Budahn, 2009; Ahmad and Chandra, 2013; Dehbandi and Aftabi, 2016; Babeesh et al., 2017; Muhs et al., 2018; Campodonico et al., 2019). Numerous trace elements ratios and plots that employ trace elements have proven to be more appropriate to identify sedimentary provenance than some traditional diagrams that involve major elements (e.g., Bathia, 1983; Roser and Korsch, 1986) which are not always reliable (e.g., Armstrong-Altrin and Verma, 2005; Caracciolo et al., 2012). In this sense, REEs, Th, Sc and high field strength elements are particularly useful to trace the origin of sedimentary deposits as these elements are almost completely transferred into the sedimentary record (e.g., Mishra and Sen, 2012). Some of these diagrams are presented here in order to constrain the provenance of Corralito I loess-paleosol sequence. Other loess from Argentina are also included for comparison. Suspended sediments from the Middle Paraná and Uruguay rivers, as well as river bed sediments and bottom lake sediments from Sierras Pampeanas, are also plotted in the diagrams as several authors pointed out that Pampean loess includes minor amounts of particles from local sources such as the Pampean ranges, the Paraná River basin and Uruguayan Precambrian outcrops (Fig. 1).

Fig. 8 shows the La-Th-Sc ternary diagrams, which allow to constrain the tectonic setting (Bathia and Crook, 1986) and to discriminate the felsic or basic provenance (Cullers, 1994) of sediments/soils. La and Th are more abundant in siliceous rocks, whereas basic rocks exhibit more contents of Sc. The loess-paleosol sequence samples as well as other loess samples from Argentina, the bottom lake sediments from Sierras Pampeanas and suspended sediments from the Paraná River plot around the field of continental arcs (Fig. 8A) and mixed sources (Fig. 8B), which encompasses a wide compositional range of igneous source rocks (i.e., from granitic to basaltic). Samples from the Uruguay River preserve the signature of metabasic sources (Fig. 8B). On the other hand, the river bed sediments from Sierras Pampeanas plot in the active and passive margins field (Fig. 8A), revealing igneous and metamorphic sources (Fig. 8B).

Floyd and Leveridge (1987) proposed a discrimination diagram which relates the $\mathrm{La} / \mathrm{Th}$ ratio with Hf to differentiate arc compositions and sources (Fig. 9). Sediments derived from acidic arcs exhibit low and uniform values of $\mathrm{La} / \mathrm{Th}$ ratio and $\mathrm{Hf}$ contents that range between 3 and $7 \mathrm{ppm}$. The Hf content increases due to the release of zircon (its main host phase), with the progressive dissection of the arc and the erosion of its roots and continental basement of ancient (meta)sedimentary rocks (Floyd and Leveridge, 1987). The Corralito I loess paleosol sequence shows low La/Th ratios $(<5)$ and Hf contents of about 4.3-5.4 ppm (Table 1) which suggests that they derive predominantly from acidic arc sources along with the suspended sediments exported by the Middle Paraná River (Fig. 9). The suspended sediments from the Middle Paraná and Uruguay rivers, as well as loess samples from Tucumán, Sierra Chica and Ancasti range reveal the influence of an old sedimentary component (Fig. 9). These loess samples exhibit higher contents of Hf likely due to the addition of alluvial material as it was already pointed out by Pasquini et al. (2017). Bottom lake sediments from Sierras Pampeanas plot close to the limit of acidic arc sources (Fig. 9). Conversely, the river bed sediments from Sierras Pampeanas do not show a clear source and those collected in Los Reartes River exhibit high Hf contents ( $>10 \mathrm{ppm}$ ).

The REEs content in clastic sediments and soils is mainly controlled by its sources in the absence of extreme chemical weathering (e.g., Cullers, 1994; Laveuf and Cornu, 2009). The diagram that uses the $\mathrm{Eu}_{\mathrm{N} *} / \mathrm{Eu}_{\mathrm{N} *} *$ vs. $\mathrm{La}_{\mathrm{N} *} / \mathrm{Yb}_{\mathrm{N} *}$ ratio, where $\mathrm{N}^{*}$ denotes normalization to chondrite (Taylor and McLennan, 1985), has been widely used in the literature to constrain the provenance of paleosols and loess (e.g., Sun et al., 2006; Hao et al., 2010; Muhs et al., 2018). It can be seen in Fig. 10 that Corralito I loess-paleosol sequence, along with loess from the Ancasti range and Buenos Aires, define a compositional field in the $\mathrm{Eu}_{\mathrm{N} *} / \mathrm{Eu}_{\mathrm{N} *} *$ vs. $\mathrm{La}_{\mathrm{N} *} / \mathrm{Yb}_{\mathrm{N} *}$ diagram. Conversely, loess from Sierra Chica and Tucumán exhibit higher $\mathrm{La}_{\mathrm{N} *} / \mathrm{Yb}_{\mathrm{N} *}$ ratios when compared to the other loess samples, likely due to the presence of alluvial material (Fig. 10). The suspended loads exported by the Middle Paraná and Uruguay rivers, as well as the river bed sediments and bottom lake sediments from Sierras Pampeanas, define other compositional fields which do not overlap with paleosol and loess samples (Fig. 10), reflecting that these sources are not significant and Pampean loess derives mainly from the Andean region (Fig. 1).

\subsection{Sedimentary recycling}

Weathering and sedimentary sorting and recycling can be analyzed by means of different geochemical approaches (e.g., McLennan et al., 1993, 2003; Meinhold et al., 2007). Recycled materials are those that have passed more than once by the exogenous cycle (e.g., McLennan, 1993). In this sense, Fig. 11A corresponds to the Th/U vs. Th plot proposed by McLennan et al. (1993). Uranium(IV) is oxidized to its soluble species $\mathrm{U}(\mathrm{VI})$ and thus it is easily mobilized during weathering and sedimentary recycling. This loss of $U$ consequently increases the $\mathrm{Th} / \mathrm{U}$ ratio values. Upper continental crust rocks show $\mathrm{Th} / \mathrm{U}$ ratios of about 3.8 (McLennan, 2001). The Th/U ratios of the loess-paleosol sequence range between 3.5 and 5, which are close to the UCC and denote incipient chemical weathering (Fig. 11A).

The relationship between Th/Sc and $\mathrm{Zr} / \mathrm{Sc}$ illustrates the compositional variation and the degree of sediment reworking and heavy mineral sorting (Fig. 11B). The Th/Sc ratio is a good overall indicator of igneous chemical differentiation processes since Th is typically an incompatible element, whereas Sc is typically a compatible element in igneous rocks (McLennan et al., 1993). Conversely, the Zr/Sc ratio constitutes a useful indicator of zircon enrichment since $\mathrm{Zr}$ is strongly enriched in this mineral, while Sc is not enriched and generally preserves the signature of its sources (McLennan, 1989). Zircon enrichment is interpreted as a clear signal of sedimentary recycling as it is a physically and chemically stable mineral, whereas in first-cycle sediments the ratios $\mathrm{Th} / \mathrm{Sc}$ and $\mathrm{Zr} / \mathrm{Sc}$ show and overall positive correlation depending on the nature of source rocks. It can be seen in Fig. 11B that Corralito I loess-paleosol samples, as well as other loess from Argentina, the suspended loads of the Middle Paraná and Uruguay rivers, and the river bed sediments and bottom lake sediments from Sierras Pampeanas, all plot around the compositional variation trend, revealing that they have undergone incipient weathering and no significant sedimentary recycling. 


\section{Conclusions}

In this contribution we provide geochemical information of the loess-paleosol sequence Corralito I in the Pampean plain of central Argentina in order to detect the weathering signature and sedimentary recycling, as well as to constrain the provenance of these deposits.

Mass balance calculations allowed the quantification of the relative gains and losses of major oxides and selected trace elements experienced by paleosol levels compared to its loess mantles. In general, the losses of some major oxides (i.e., $\mathrm{CaO}, \mathrm{Na}_{2} \mathrm{O}$ ) and $\mathrm{Sr}$ in the buried soil and paleosols reflect the weathering of plagioclase. The chemical alteration of K-feldspar in the buried soil and paleosols I and II is suggested by the losses of $\mathrm{K}_{2} \mathrm{O}$ and $\mathrm{Ba}$. The relative losses of As in almost all levels likely reflects the chemical alteration of volcanic glass. Conversely, pyroxenes and amphiboles or Fe oxy-hydroxides are concentrated in paleosols and the buried soil evidenced by the relative gains of $\mathrm{Fe}_{2} \mathrm{O}_{3}$ and $\mathrm{MgO}$. Chemical weathering indices and ratios (i.e., CIA, CIW, PIA, LWI, CaO/TiO, $\mathrm{Na}_{2} \mathrm{O} / \mathrm{TiO}_{2}$ and $\mathrm{Rb} / \mathrm{Sr}$ ), as well as the A$\mathrm{CN}-\mathrm{K}$ ternary diagram, reveal an incipient degree of chemical alteration in the sequence, which is slightly greater in the paleosols when compared to loess mantles and coherent with a weathering-limited erosional regime.

The compositional diagrams used in this paper to constrain the origin of loess deposits (e.g., La-Th-Sc ternary diagram, La/Th vs. Hf plot, $\mathrm{Eu}_{\mathrm{N} *} / \mathrm{Eu}_{\mathrm{N} *} *$ vs. $\mathrm{La}_{\mathrm{N} *} / \mathrm{Yb}_{\mathrm{N} *}$ diagram) indicate that Pampean loess derives mainly from the Andean region and that the contributions from other minor local sources that were pointed out in previous contributions (i.e., Pampean ranges, the Paraná River basin and Uruguayan Precambrian outcrops) are not significant. Besides, no sedimentary recycling was distinguished throughout Corralito I loess-paleosol sequence and other loess samples from Argentina, suggesting that they are mainly composed by young materials derived from undifferentiated volcanic rocks.

\section{Acknowledgements}

This research was funded by the Consejo Nacional de Investigaciones Científicas y Técnicas (CONICET, Argentina, PIP 112200801-03160), the Agencia Nacional de Promoción Científica y Tecnológica (ANPCyT, Argentina, PICT-2012-0275) and the Universidad Nacional de Córdoba (SeCyT, UNC 05/1711).

\section{References}

Ahmad, I., Chandra, R., 2013. Geochemistry of loess-paleosol sediments of Kashmir Valley, India: provenance and weathering. J. Asian Earth Sci. 66, 73-89.

Argüello, G.L., Dasso, C.M., Sanabria, J.A., 2006. Effects of intense rainfalls and their recurrence: case study in Corralito ravine, Córdoba Province, Argentina. Quat. Int. $158,140-146$.

Argüello, G.L., Dohrmann, R., Sanabria, J.A., Zahn, E., 2010. Genetic implications of a retransported loess profile near Córdoba, Argentina. J. S. Am. Earth Sci. 29, 642-649.

Argüello, G.L., Dohrmann, R., Mansilla, L., 2012. Chapter I Loess of Córdoba (Argentine) Central Plain, present state of knowledge and new results of research. In: Rossi, A., Miranda, L. (Eds.), Argentina: Environmental, Geographical and Cultural Issues. Nova Science Pub Incorporated, New York, pp. 1-49.

Armstrong-Altrin, J.S., Verma, S.P., 2005. Critical evaluation of six tectonic setting discrimination diagrams using geochemical data of Neogene sediments from known tectonic settings. Sediment. Geol. 177, 115-129.

Babeesh, C., Achyuthan, H., Jaiswal, M., Lone, A., 2017. Late quaternary loess-like paleosols and pedocomplexes, geochemistry, provenance and source area weathering, Manasbal, Kashmir Valley, India. Geomorphology 284, 191-205.

Bathia, M.R., 1983. Plate tectonics and geochemical composition of sandstones. J. Geol. 91, 611-627.

Bathia, M.R., Crook, K.A.W., 1986. Trace element characteristics of graywackes and tectonic setting discrimination of sedimentary basins. Contrib. Mineral. Petrol. 92, 181-193.

Bertolino, S., Zimmermann, U., Sattler, F., 2007. Mineralogy and geochemistry of bottom sediments from water reservoirs in the vicinity of Córdoba, Argentina: environmental and health constraints. Appl. Clay Sci. 36, 206-220.

Bia, G., García, M.G., Borgnino, L., 2017. Changes in the As solid speciation during weathering of volcanic ashes: a XAS study on Patagonian ashes and Chacopampean loess. Geochim. Cosmochim. Acta 212, 119-132.
Borgnino, L., Garcia, M.G., Bia, G., Stupar, Y., Le Coustumer, P.H., Depetris, P.J., 2013. Mechanisms of fluoride release in sediments of Argentina's central region. Sci. Total Environ. 443, 245-255.

Bostick, B., Vairavamurthy, M., Karthikeyan, K.G., Chorover, J., 2002. Cesium adsorption on clay minerals: an EXAFS spectroscopic investigation. Environ. Sci. Technol. 36, 2670-2676.

Braun, J.-J., Pagel, M., Muller, J.-P., Bilong, P., Michard, A., Guillet, B., 1990. Cerium anomalies in lateritic profiles. Geochim. Cosmochim. Acta 54, 781-795.

Braun, J.-J., Viers, J., Dupré, B., Polve, M., Ndam, J., Muller, J.-P., 1998. Solid/liquid REE fractionation in the lateritic system of Goyoum, East Cameroon: the implication for the present dynamics of the soil covers of the humid tropical regions. Geochim. Cosmochim. Acta 62 (2), 273-299.

Buggle, B., Glaser, B., Hambach, U., Gerasimenko, N., Marković, S., 2011. An evaluation of geochemical weathering indices in loess-paleosol studies. Quat. Int. 240, 12-21.

Campodonico, V.A., Martínez, J.O., Verdecchia, S.O., Pasquini, A.I., Depetris, P.J., 2014. Weathering assessment in the Achala Batholith of the Sierra de Comechingones, Córdoba, central Argentina. I: granite regolith fractionation. Catena 123, 121-134.

Campodonico, V.A., García, M.G., Pasquini, A.I., 2016. The geochemical signature of suspended sediments in the Paraná River basin: implications for provenance, weathering and sedimentary recycling. Catena 143, 201-214.

Campodonico, V.A., Pasquini, A.I., Lecomte, K.L., García, M.G., Depetris, P.J., 2019. Chemical weathering in subtropical basalt-derived laterites: a mass balance interpretation (Misiones, NE Argentina). Catena 173, 352-366.

Cantú, M., 1992. Provincia de C!ordoba. In: Iriondo, M. (Ed.), El Holoceno en la Argentina, Paraná. CADINCUA, Argentina, pp. 1-16.

Cantú, M., Degiovanni, S., 1984. Geomorfolog!ıa de la región centro sur de la provincia de Córdoba. In: Noveno Congreso Geológico Argentino, S.C. de Bariloche, ACTAS IV, pp. 76-92.

Caracciolo, L., Von Eynatten, H., Tolosana-Delgado, R., Critelli, S., Manetti, P., Marchev, P., 2012. Petrological, geochemical, and statistical analysis of Eocene-Oligocene sandstones of the Western Thrace basin, Greece and Bulgaria. J. Sediment. Res. 82, 482-498.

Carignano, C., Kröhling, D., Degiovanni, S., Cioccale, M., 2014. Geomorfología. In: Martino, R., Guereschi, A. (Eds.), Relatorio XIX Congreso Geológico Argentino, pp. 747-843 Córdoba.

Carson, M.A., Kirkby, M.J., 1972. Hillslope form and process. Science 178, 1083-1084.

Caspari, T., Bäumler, R., Norbu, C., Tshering, K., Baillie, I., 2006. Geochemical investigation of soils developed in different lithologies in Bhutan, eastern Himalayas. Geoderma 136, 436-458.

Chen, J., An, Z., Liu, L., Ji, J., Yang, J., Chen, Y., 2001. Variations in chemical compositions of the eolian dust in Chinese Loess Plateau over the past $2.5 \mathrm{Ma}$ and chemical weathering in the Asian inland. Sci. China (Series D) 44 (5), 403-413.

Condie, K.C., 1993. Chemical composition and evolution of the upper continental crust: contrasting results from surface samples and shales. Chem. Geol. 104, 1-37.

Cullers, R.L., 1994. The chemicals signature of source rocks in size fractions of Holocene stream sediments derived from metamorphic rocks in the West Mountains region, Colorado, USA. Chem. Geol. 113, 327-343.

Dehbandi, R., Aftabi, A., 2016. Geochemical provenance of soils in Kerman urban areas, Iran: implications for the influx of aeolian dust. Aeolian Res. 21, 109-123.

Depetris, P.J., Pasquini, A.I., 2007. The geochemistry of the Paraná River: an overview. In: Iriondo, M.H., Paggi, J.C., Parma, M.J. (Eds.), The Middle Paraná River: Limnology of a Subtropical Wetland. Springer, Berlin Heidelberg, New York, pp. 143-174.

Depetris, P.J., Pasquini, A.I., Lecomte, K.L., 2014. Weathering and the Riverine Denudation of Continents. Springer, Berlin, pp. 95.

Döering, A., 1907. La Formation Pampéenne de Córdoba. Revista del Museo de La Plata 14, 461-465.

Elderfield, H.R., Upstill-Goddard, R., Sholkovitz, E.R., 1990. The rare earth elements in rivers, estuaries and coastal sea waters: processes affecting crustal input of elements to the ocean and their significance to the composition of sea water. Geochim. Cosmochim. Acta 54, 971-991.

Etchichury, M., Tófalo, O., 2004. Mineralogía de arenas y limos en suelos, sedimentos fluviales y eólicos actuales del sector austral de la cuenca Chacoparanaense. Regionalización y áreas de aporte. Rev. Asoc. Geol. Argent. 59 (2), 317-329.

Fedo, C.M., Nesbitt, H.W., Young, G.M., 1995. Unraveling the effects of potassium metasomatism in sedimentary rocks and paleosols, with implications for paleoweathering conditions and provenance. Geology 23, 921-924.

Floyd, P.A., Leveridge, B.E., 1987. Tectonic environment of Devonian Gramscatho basin, south Cornwall: framework mode and geochemical evidence from turbiditic sandstones. J. Geol. Soc. 144 (4), 531-542.

Frechen, M., Oches, E., Kohfeld, K., 2003. Loess in Europe-mass accumulation rates during the Last Glacial Period. Quat. Sci. Rev. 22, 1835-1857.

Frechen, M., Seifert, B., Sanabria, J., Argüello, G., 2009. Chronology of Late Pleistocene Pampa loess from the Córdoba area in Argentina. J. Quat. Sci. 24 (7), 761-772.

Frenguelli, J., 1918. Notas preliminares sobre la constitución geológica del subsuelo en la ciudad de Córdoba. Boletín de la Academia Nacional de Ciencias de Córdoba XXIII, 203-220.

Frenguelli, J., 1955. Loess y Limos pampeanos. Serie técnica y didáctica no. 7 Ministerio de Educación de la Nación, La Plata, pp. 88.

Gallet, S., Jahn, B., Lanoë, B., Dia, A., Rossello, E., 1998. Loess geochemistry and its implications for particle origin and composition of the upper continental crust. Earth Planet. Sci. Lett. 156, 157-172.

Gili, S., Gaiero, D.M., Goldstein, S.L., Chemale Jr., F., Jweda, J., Kaplan, M., Becchio, R., Koester, E., 2017. Glacial/interglacial changes of Southern Hemisphere wind circulation from the geochemistry of South American dust. Earth Planet. Sci. Lett. 469, 98-109. 
Girty, G.H., Marsh, J., Meltzner, A., McConnell, J., Nygren, D., Nygren, J., Prince, G., Randall, K., Johnson, D., Heitman, B., Nielsen, J., 2003. Assessing changes in elemental mass as a result of chemical weathering of granodiorite in a mediterranean (hot summer) climate. J. Sediment. Res. 73 (3), 434-443.

Girty, G.H., Gebhart, K.L., Replogle, C.T., Morton, N., Purcell, J.W., Parizek, J.R., Carrasco, T., Errthum, R., Groover, K., 2014. Reconstructing the regolith from erosionally exhumed corestone and saprock derived from the Cretaceous Val Verde tonalite, Peninsular Ranges, southern California, USA: a case study. Catena 113, $150-164$.

Gorgas, J., Tassile, J., Jarsún, B., Zamora, E., Bosnero, H., Lovera, E., Ravelo, A., 2006 Los Suelos. Nivel de reconocimiento 1:500.000. In: Recursos Naturales de la Provincia de Córdoba. INTA (Instituto Nacional de Tecnología Agropecuaria), Argentina.

Hannigan, R., Sholkovitz, E., 2001. The development of middle rare earth element enrichments in freshwaters: weathering of phosphate minerals. Chem. Geol. 175 (3-4), 495-508.

Hao, Q., Guo, Z., Qiao, Y., Xu, B., Oldfield, F., 2010. Geochemical evidence for the provenance of middle Pleistocene loess deposits in southern China. Quat. Sci. Rev. 29 (23), 3317-3326.

Harnois, L., 1988. The CIW index: a new chemical index of weathering. Sediment. Geol. 55 (3-4), 319-322.

Heusser, J.C., Claraz, G., 1866. Essai pour servir a une description physiqye et geognostique de la province argentine de buenos ayres. Memoire Societé Helvetique Science Naturelles 21, 139.

Hofmann, A., 1988. Chemical differentiation of the Earth: the relationship between mantle, continental crust, and oceanic crust. Earth Planet. Sci. Lett. 90 (3), 297-314.

Iriondo, M., 1990. The upper Holocene dry period in the Argentine plains. In: Rabassa, J. (Ed.), Quaternary of South America and Antartic Peninsula. vol. 7. AA Balkema Publ, Rotterdam, pp. 197-217.

Iriondo, M., 1997. Models of deposition of loess and loessoids in the upper Quaternary of South America. J. S. Am. Earth Sci. 10 (1), 71-79.

Iriondo, M., Kröhling, D., 1995. El Sistema Eólico Pampeano. Comunicación Museo Provincial de Ciencias Naturales Florentino Ameghino, Santa Fe, pp. 1-68 5(1).

Iriondo, M., Kröhling, D., 1997. The tropical loess. In: An, Z., Zhou, W. (Eds.), Quaternary Geology. Proceedings of the 30th International Geological Congress, Beijing. vol. 21. pp. 61-77.

Johanesson, K., Zhou, X., 1999. Origin of middle rare earth element enrichments in acid waters of a Canadian High Arctic lake. Geochim. Cosmochim. Acta 63 (1), 153-165.

Kemp, R.A., 2001. Pedogenic modification of loess: significance for palaeoclimatic reconstruction. Earth Sci. Rev. 54, 145-156.

Kröhling, D.M., 1999. Sedimentological maps of the typical loessic units in North Pampa, Argentina. Quat. Int. 62, 49-56.

Kühn, P., Techmer, A., Weidenfeller, M., 2013. Lower to middle Weichselian pedogenesis and palaeoclimate in Central Europe using combined micromorphology and geochemistry: the loess-paleosol sequence of Alsheim (Mainz Basin, Germany). Quat. Sci. Rev. 75, 43-58.

Laveuf, C., Cornu, S., 2009. A review on the potentiality of Rare Earth Elements to trace pedogenetic processes. Geoderma 154, 1-12.

Li, Y., Song, Y., Chen, X., Li, J., Mamadjanov, Y., Aminov, J., 2016. Geochemical composition of Tajikistan loess and its provenance implications. Palaeogeogr. Palaeoclimatol. Palaeoecol. 446, 186-194.

McLennan, S.M., 1989. Rare-earth elements in sedimentary rocks. Influence of provenance and sedimentary processes. In: Lipin, B., McKay, G. (Eds.), Geochemistry and Mineralogy of Rare Earth Elements. Mineralogical Society of America, pp. 169-200.

McLennan, S.M., 1993. Weathering and global denudation. J. Geol. 101, 295-303.

McLennan, S.M., 2001. Relationships between the trace element composition of sedimentary rocks and upper continental crust. Geochem. Geophys. Geosyst. 2 (4). https://doi.org/10.1029/2000GC000109.

McLennan, S.M., Hemming, D.K., Hanson, G.N., 1993. Geochemical approaches to sedimentation, provenance and tectonics. Geol. Soc. Am. Spec. Pap. 284, 21-40.

McLennan, S.M., Bock, B., Hemming, S., Hurowitz, J., Lev, S., McDaniel, D., 2003. The roles of provenance and sedimentary processes in the geochemistry of sedimentary rocks. In: Lentz, D. (Ed.), Geochemistry of Sediments and Sedimentary Rocks. Geological Association of Canada, pp. 7-38 Geotext 5.

Meinhold, G., Kostopoulos, D., Reischmann, T., 2007. Geochemical constraints on the provenance and depositional setting of sedimentary rocks from the islands of Chios, Inousses and Psara, Aegean Sea, Greece: implications for the evolution of Palaeotethys. J. Geol. Soc. 164, 1145-1163.

Mishra, M., Sen, S., 2012. Provenance, tectonic setting and source-area weathering of Mesoproterozoic Kaimur Group, Vindhyan Supergroup, Central India. Geol. Acta 10 (3), 283-293.

Morrás, H., 1999. Geochemical differentiation of Quaternary sediments from the Pampean region based on soil phosphorus contents as detected in the early 20th century. Quat. Int. 62, 57-67.

Muhs, D., Budahn, J., 2006. Geochemical evidence for the origin of late Quaternary loess in central Alaska. Can. J. Earth Sci. 43, 323-337.

Muhs, D., Budahn, J., 2009. Geochemical evidence for African dust and volcanic ash inputs to terra rossa soils on carbonate reef terraces, northern Jamaica, West Indies. Quat. Int. 196, 13-35.

Muhs, D., Bettis III, E., Been, J., McGeehin, J., 2001. Impact of climate and parent material on chemical weathering in loess-derived soils of the Mississippi River Valley. Soil Sci. Soc. Am. J. 65, 1761-1777.

Muhs, D., Ager, T., Bettis III, E., McGeehin, J., Been, J., Begét, J., Pavich, M., Stafford Jr., T., Stevens, D., 2003. Stratigraphy and palaeoclimatic significance of Late Quaternary loess-palaeosol sequences of the last interglacial-glacial cycle in Central Alaska. Quat. Sci. Rev. 22, 1947-1986.
Muhs, D.R., Pigati, J.S., Budahn, J.R., Skipp, G.L., Bettis III, E.A., Jensen, B., 2018. Origin of last-glacial loess in the western Yukon-Tanana Upland, central Alaska, USA. Quat. Res. 89 (3), 797-819.

Nesbitt, H.W., 1979. Mobility and fractionation of rare earth elements during weathering of a granodiorite. Nature 279, 206-210.

Nesbitt, H.W., Young, G.M., 1982. Early Proterozoic climates and plate motions inferred from major element chemistry of lutites. Nature 299 (5885), 715-717.

Nesbitt, H.W., Markovics, G., Price, R.C., 1980. Chemical processes affecting alkalis and alkaline earths during continental weathering. Geochim. Cosmochim. Acta 44 (11), 1659-1666.

Nesbitt, H.W., Young, G.M., McLennan, S.M., Keays, R.R., 1996. Effects of chemical weathering and sorting on the petrogenesis of siliciclastic sediments, with implications for provenance studies. J. Geol. 104, 525-542.

Nicolli, H., Bundschuh, J., Garcia, J., Falcón, C., Jean, J., 2010. Sources and controls for the mobility of arsenic in oxidizing groundwaters from loess-type sediments in arid/ semi-arid dry climates - evidence from the Chaco-Pampean plain (Argentina). Water Res. 44, 5589-5604.

Pánario, D., Gutiérrez, O., 1999. The continental Uruguayan Cenozoic: an overview. Quat. Int. 62, 75-84.

Pasquini, A.I., Lecomte, K.L., Depetris, P.J., 2004. Geoquímica de ríos de montaña en las Sierras Pampeanas: II. El río Los Reartes, sierra de Comenchingones, provincia de Córdoba. Rev. Asoc. Geol. Argent. 59 (1), 129-140.

Pasquini, A.I., Campodonico, V.A., Rouzaut, S., Giampaoli, V., 2017. Geochemistry of a soil catena developed from loess deposits in a semiarid environment, Sierra Chica de Córdoba, central Argentina. Geoderma 295, 53-68.

Polanski, J., 1963. Estratigrafía, Neotectónica y Geomorfología del Pleistoceno pedemontano entre los ríos Diamante y Mendoza. Rev. Asoc. Geol. Argent. XVII (3-4), 127-349.

Porter, S.C., 2007. Loess record - China. In: Scott, E. (Ed.), Encyclopedia of Quaternary Science. Elsevier, Amsterdam, pp. 1429-1440.

Potter, P.E., Maynard, J.B., Depetris, P.J., 2005. Mud and Mudstones. Springer - Verlag, Berlin, pp. 297.

Price, J., Velbel, M., 2003. Chemical weathering indices applied to weathering profiles developed on heterogeneous felsic metamorphic parent rocks. Chem. Geol. 202, $397-416$.

Pye, K., 1995. The nature, origin and accumulation of loess. Quat. Sci. Rev. 14, 663-667.

Pye, K., Sherwin, W., 1999. Loess. In: Goudie, A., Livingstone, I., Stokes, S. (Eds.), Aeolian Environments Sediments and Landforms. Wiley, Chichester, pp. 213-240.

Reuter, G., 2000. A logical system of paleopedoligical terms. Catena 41, 93-109.

Roser, B.P., Korsch, R.J., 1986. Determination of tectonic setting sandstones-mudstone suites using $\mathrm{SiO}_{2}$ content and $\mathrm{K}_{2} \mathrm{O} / \mathrm{Na}_{2} \mathrm{O}$ ratio. J. Geol. 94 (5), 635-650.

Rouzaut, S., Orgeira, M.J., 2017. Influence of volcanic glass on the magnetic signal of different paleosols in Córdoba, Argentina. Stud. Geophys. Geod. 61, 361-384.

Rouzaut, S., Orgeira, M.J., Vásquez, C., Argüello, G., Sanabria, J., 2012a. Magnetic properties in a loess-paleosol sequence of Córdoba, Argentina. Rev. Soc. Geol. Esp. 25 (1-2), 55-63.

Rouzaut, S., Orgeira, M.J., Vásquez, C., Sanabria, J., Argüello, G., Bachmeier, O., 2012b. Estudio de magnetismo de rocas en una serie de suelo con vegetación autóctona y cultivados en el centro de la provincia de Córdoba, Argentina. Geoacta 37 (2), 67-72.

Rouzaut, S., Orgeira, M.J., Tófalo, O., Vásquez, C., Argüello, G., Sanabria, J., Mansilla, L., 2013. Estudio comparativo de propiedades magnéticas en la región central de la provincia de Córdoba, Argentina. Geoacta 38 (2), 128-139.

Rouzaut, S., Orgeira, M.J., Vásquez, C., Ayala, R., Argüello, G., Tauber, A., Tófalo, R., Mansilla, L., Sanabria, J., 2015. Rock magnetism in two loess-paleosol sequences in Córdoba, Argentina. Environ. Earth Sci. 73 (10), 6323-6339.

Sayago, J.M., 1995. The Argentinian neotropical loess: an overview. Quat. Sci. Rev. 14, $755-766$.

Scott, K.M., 2009. Appendix 2: regolith geochemistry of elements. In: Scott, K., Pain, C. (Eds.), Regolith Science. Springer-CSIRO Publishing, Dordrecht-Melbourne, pp. 434-452.

Sepúlveda, L.D., Lecomte, K.L., Pasquini, A.I., Mansilla, E.G., Chaparro, M.A.E., 2019. Propiedades geoquímicas y magnéticas de sedimentos como indicadores de contaminación. Caso de estudio: Río Suquía, Córdoba, Argentina. Revista Mexicana de Ciencias Geológicas (in press).

Smedley, P.L., Nicolli, H.B., Macdonald, D.M., Barros, A.J., Tullio, J.O., 2002. Hydrogeochemistry of arsenic and other inorganic constituents in groundwaters from La Pampa, Argentina. Appl. Geochem. 17 (3), 259-284.

Smith, J., Vance, D., Kemp, R.A., Archer, C., Toms, P., King, M., Zárate, M., 2003. Isotopic constraints on the source of Argentine loess-with implications for atmospheric circulation and the provenance of Antarctic dust during recent glacial maxima. Earth Planet. Sci. Lett. 6682, 1-16.

Soil Survey Staff, 2014. Keys to Soil Taxonomy, 12th ed. USDA-Natural Resources Conservation Service, Washington DC, pp. 331

Stallard, R.F., Edmond, J.M., 1983. Geochemistry of the Amazon: 2. The influence of geology and weathering environment on the dissolved load. J. Geophys. Res. Oceans 88, 9671-9688.

Sun, J., Li, S.-H., Muhs, D.R., Li, B., 2006. Loess sedimentation in Tibet: provenance, processes, and link with Quaternary glaciations. Quat. Sci. Rev. 26, 2265-2280.

Sun, Z.-X., Jiang, Y.-Y., Wang, Q.-B., Owens, P.R., 2018. Geochemical characterization of the loess-paleosol sequence in northeast China. Geoderma 321, 127-140.

Taylor, S.R., McLennan, S.M., 1985. The Continental Crust: Its Composition and Evolution. Blackwell, Boston, pp. 312.

Teruggi, M.E., 1957. The nature and origin of the Argentine loess. J. Sediment. Petrol. 27, $322-332$.

Tugulan, L.C., Duliu, O.G., Boja, A., Dumitras, D., Zimicovskaia, I., Culicov, O., Frontasyeva, M., 2016. On the geochemistry of the Late Quaternary loess deposits of 
Dobrogea (Romania). Quat. Int. 399, 100-110.

Újvári, G., Varga, A., Balogh-Brunstad, Z., 2008. Origin, weathering, and geochemical composition of loess in southwestern Hungary. Quat. Res. 69, 421-437.

Újvári, G., Varga, A., Raucsik, B., Kovács, J., 2014. The Paks loess-paleosol sequence: a record of chemical weathering and provenance for the last $800 \mathrm{ka}$ in the midCarpathian Basin. Quat. Int. 319, 22-37.

World Reference Base for Soil Resources, 2006. In: IUSS Working Group (Ed.), 2nd edition. World Soil Resourses Reports $N^{\circ} 103$ FAO, Rome.

Woronow, A., Love, K.M., 1990. Quantifying and testing differences among means of compositional data suites. Math. Geol. 22 (7), 837-852.

Yang, S., Ding, F., Ding, Z., 2006. Pleistocene chemical weathering history of Asian arid and semi-arid regions recorded in loess deposits of China and Tajikistan. Geochim. Cosmochim. Acta 70 (7), 1695-1709.

Zárate, M., 2003. Loess of southern South America. Quat. Sci. Rev. 22, 1987-2006.

Zárate, M., Kemp, R.A., Blasi, A., 2002. Identification and differentiation of Pleistocene paleosols in the northern Pampas of Buenos Aires, Argentina. J. S. Am. Earth Sci. 15, 303-313. 